\title{
Testing the utility of structure from motion photogrammetry reconstructions using small unmanned aerial vehicles and ground photography to estimate the extent of upland soil erosion
}

Short title: Testing small unmanned aerial vehicles and ground photography for erosion monitoring

Miriam Glendell* $(1,2)$, Gareth McShane (3), Luke Farrow (1), Mike R. James (3), John Quinton (3), Karen Anderson (4), Martin Evans (5), Pia Benaud (1), Barry Rawlins (6), David Morgan (6), Lee Jones (6), Matthew Kirkham (6), Leon DeBell (5),Timothy A. Quine (1), Murray Lark (6), Jane Rickson (7), Richard E. Brazier (1)

(1) University of Exeter, Geography - College of Life and Environmental Sciences, Exeter EX4 4RJ (2) The James Hutton Institute, Craigiebuckler, Aberdeen AB15 8QH (3) Lancaster Environment Centre, Lancaster University, Bailrigg, Lancaster LA1 4YQ (4) Environment and Sustainability Institute, University of Exeter, Penryn Campus, Penryn, Cornwall TR10 9FE (5) Arthur Lewis Building-1.029, School of Environment, Education and Development, The University of Manchester, Manchester M13 9PL (6) British Geological Survey, Environmental Science Centre, Nicker Hill, Keyworth, Nottingham NG12 5GG (7) Environmental Science and Technology Department, Applied Sciences, Cranfield University, Cranfield MK43 $O A L$

Published by Wiley. This is the Author Accepted Manuscript issued with: Please refer to any applicable publisher terms of use.

This article has been accepted for publication and undergone full peer review but has not been through the copyediting, typesetting, pagination and proofreading process which may lead to differences between this version and the Version of Record. Please cite this article as doi: $10.1002 /$ esp.4142 
*corresponding author: The James Hutton Institute, Craigiebuckler, Aberdeen AB15 8QH, Scotland, UK, Miriam.Glendell@hutton.ac.uk, tel: +44(0)1224 395 320, fax: $+44(0) 8449285429$

\section{Abstract}

Quantifying the extent of soil erosion at a fine spatial resolution can be time consuming and costly; however, proximal remote sensing approaches to collect topographic data present an emerging alternative for quantifying soil volumes lost via erosion. Herein we compare terrestrial laser scanning (TLS), and both aerial (UAV) and ground-based (GP) SfM derived topography. We compare the costeffectiveness and accuracy of both SfM techniques to TLS for erosion gully surveying in upland landscapes, treating TLS as a benchmark. Further, we quantify volumetric soil loss estimates from upland gullies using digital surface models derived by each technique and subtracted from an interpolated pre-erosion surface. Soil loss estimates from UAV and GP SfM reconstructions were comparable to those from TLS, whereby the slopes of the relationship between all three techniques were not significantly different from 1:1 line. Only for the TLS to GP comparison the intercept was significantly different from zero, showing that GP is more capable of measuring the volumes of very small erosion features. In terms of cost-effectiveness in data collection and processing time, both UAV and GP were comparable with the TLS on a per-site basis (13.4 and 8.2 person-hours versus 13.4 for TLS); however GP was less suitable for surveying larger areas (127 person-hours per ha ${ }^{-1}$ versus 4.5 for UAV and 3.9 for TLS). Annual repeat surveys using GP were capable of detecting mean vertical erosion change on peaty soils. These first published estimates of whole gully erosion rates $\left(0.077 \mathrm{~m} \mathrm{a}^{-1}\right)$ suggest that combined erosion 
rates on gully floors and walls are around three times the value of previous estimates, which largely characterise wind and rainsplash erosion of gully walls.

Keywords: soil erosion monitoring, SfM photogrammetry, upland gully erosion, lightweight drones, terrestrial laser scanning

\section{Introduction}

Upland landscapes provide important multiple ecosystem services, including drinking water provision, flood regulation, carbon sequestration, natural and cultural heritage and recreation (Grand-Clement et al., 2013). Most of these functions are affected by soil health, which may be impaired by accelerated soil erosion rates (Evans and Lindsay, 2010b; McHugh, 2007; Warburton et al., 2003). Soil erosion has been defined as "the accelerated loss of soil as a result of anthropogenic activity in excess of accepted rates of natural soil formation" (Gregory et al., 2015), currently estimated at ca. $1 \mathrm{tha}^{-1} \mathrm{a}^{-1}$ (Verheijen et al., 2012), although reliable national estimates of soil formation and soil erosion rates are rarely available (Brazier et al., 2016). Therefore, quantifying the rates of soil erosion and understanding the significance of erosion impacts on upland ecosystem services, as well as the effectiveness of any remediation measures, requires an ability to quantify the volume and spatial extent of erosion features accurately (Evans and Lindsay, 2010a). 
In the last decade, advances in remote sensing technology have greatly facilitated the mapping of erosion processes and quantification of their magnitude. Airborne and terrestrial Light Detection And Ranging (LiDAR) sensors have become the mainstay for production of detailed topographic surface models for a variety of geoscience applications, including the study of landslides (Jaboyedoff, M.; Oppikofer, T.; Abellan, A.; Derron, M.-H.; Loye, A.; Metzger, R.; Pedrazzini et al., 2012), channel networks (Passalacqua et al., 2010; Sofia et al., 2011), river morphology and morphodynamics (Legleiter, 2012; Williams et al., 2014, 2015), active tectonics (Hilley and Arrowsmith, 2008), volcanoes (Kereszturi et al., 2012) and agricultural landscapes (Cazorzi et al., 2013; Passalacqua et al., 2015; Sofia et al., 2014; Tarolli, 2014). However, Airborne Laser Scanning (ALS) and Terrestrial Laser Scanning (TLS) surveys remain costly, particularly where time-series data are required, while having additional limitations in terms of range and line of sight. Consequently, there is a need to develop alternative methodologies that can provide high-resolution topographic data cost-effectively and at user-defined time-steps (Hugenholtz et al., 2015). Structure from Motion (SfM) photogrammetry is emerging as a powerful tool in the geosciences, offering the capability to derive high-resolution digital elevation models (DEMs) from overlapping, convergent digital images (Bemis et al., 2014; Carrera-Hernández et al., 2016; Carrivick et al., 2016; James and Robson, 2012; Javernick et al., 2014; Lucieer et al., 2014; Nouwakpo et al., 2016; Reitman, N.G., 2015; Smith et al., 2014; Smith et al., 2015; Snapir et al., 2014; Stumpf et al., 2015; Tonkin et al., 2014; Westoby et al., 2012). In upland landscapes, where soil erosion mapping is hindered by remoteness and terrain complexity, SfM topographic reconstruction may be a more portable and affordable approach than TLS and ALS. 
Surface reconstruction based on ground photography (GP) has been shown to be a suitable tool for topographic studies at scales between 10 and 100 m extents (James and Robson, 2012; Smith et al., 2014), whilst TLS has been applied up to $3500 \mathrm{~m}$ ranges. As the latter depends on the capability of the TLS instrument and the complexity of the landscape being studied (James et al., 2009), mobile platforms (scan as you go or move-stop-scan) may further help to increase TLS survey ranges and reduce survey time (James and Quinton, 2014). Meanwhile, unmanned aerial vehicles (UAVs), allow combining the strengths of both techniques, with increasingly available, low-cost, agile, lightweight UAV platforms, self-service data capture at user-defined time steps and affordable SfM software. As SfM topography becomes more popular in geoscience studies (for example: Cunliffe et al., 2016; Hugenholtz et al., 2013; Ouédraogo et al., 2014; Smith and Vericat, 2015; Tonkin et al., 2014; Turner et al., 2015; Woodget et al., 2015), a quantitative understanding of the accuracy, cost-effectiveness, and limitations of this technique grows increasingly important (Hugenholtz et al., 2015); especially for applications that demand highresolution data products.

While a variety of papers have compared the accuracy of high resolution topographic models generated with UAVs against traditional total station surveys (Smith and Vericat, 2015; Tonkin et al., 2014; Woodget et al., 2015), real-time kinematic DGPS surveys (Hugenholtz et al., 2013; Turner et al., 2015; Woodget et al., 2015), with TLS (Johnson et al., 2014; Ouédraogo et al., 2014; Smith and Vericat, 2015) and ALS (Johnson et al., 2014), the authors are not aware of any work that has compared the spatial and volumetric accuracy of UAV derived DEMs with those 
derived from GP, using TLS derived DEM as a reference, in a single application. Therefore this research aims to:

a) assess the accuracy of SfM techniques as practical tools to measure upland erosion,

b) understand quantitatively how well the technology could be used to evaluate annual erosion rates across a range of upland erosion types and

c) evaluate the cost-effectiveness of the three techniques in upland landscapes.

\section{Material and methods}

\section{Study sites}

Ten upland sites across the UK with a propensity for soil erosion were selected for survey, with a target survey area of 16 ha (Fig.1, Table 1). These sites were distributed across England and Wales and included different types of erosion features and different soil types. In 2014, 24 gully features were surveyed at eight sites. In 2015, 11 gullies were re-surveyed at five locations and a further four gullies were surveyed at two additional locations. Gully dimensions ranged between 104 and $1238 \mathrm{~m}^{2}$ (Appendix 1). Figure 2 shows an example study site and data fragmentation workflow. 


\section{Field survey}

\section{UAV imaging surveys}

Aerial images were collected using a lightweight UAV - a 3D Robotics IRIS+ quadcopter fitted with a Canon Powershot A2500 or Canon SX260 HS camera attached via a directional gimbal pointing at nadir. The UAV was equipped with a Pixhawk flight controller and flight plans were programmed using Mission Planner (v1.3.32) software so that the images overlapped approximately $65 \%$ endlap and $55 \%$ sidelap, ground speed set to $2.5 \mathrm{~m} \mathrm{~s}^{-1}$ in year one and $2 \mathrm{~m} \mathrm{~s}^{-1}$ in year two. Although smaller than the ideal overlap recommended by Photoscan $(80 \%$ endlap and $60 \%$ sidelap), the image overlap was maximised by using the smallest achievable photo interval, given camera constraints and target survey area extent. The cameras were triggered using the "Canon Hack Development Kit" CHDK KAP UAV control script (http://chdk.wikia.com/wiki/KAP UAV Exposure Control Script) to control the exposure, shutter speed and aperture for high image quality. During the first year of field work in 2014, the Canon Powershot A2500 16 MP camera (28 $\mathrm{mm}$ lens) was used, with an automatic triggering every 3 seconds. In 2015, the Canon SX260 HS 12 MP (25 mm lens) was used at a number of sites (Table 2), as it provided a greater range of available ISO, shutter speed settings and a shorter image capture frequency of $2.5 \mathrm{~s}$. In all flights the camera focal length was set to infinity whilst the exposure settings varied between 100 and 1600 ISO, shutter speed between 1/1600 and 1/500 second and aperture between F2.8 and F8. Settings were chosen so as to maximise light sensitivity (ISO) and minimise exposure time 
and aperture in order to ensure greatest image sharpness and depth of focus. Achieved ground resolution was between 0.6 and $1.1 \mathrm{~cm}$ (Table 2).

Table 3 and Appendix 1 provide full details of all ground based validation surveys. Up to 30 ground control point (GCP) targets were deployed in a grid over the target survey area, with coordinates measured by high accuracy real-time kinematic (RTK) DGPS instruments. We used either a Leica GS08+ base/rover system or a Trimble R4 GNSS surveying system for surveying purposes and both had an estimated 3D observation accuracy of $2 \mathrm{~cm}$. The RTK-GPS observations were obtained using a local base and were post processed using the UK Ordnance Survey Static Network. In 2014, black and white crossed targets ( 10 cm across) were used as GCPs. In 2015, these were replaced with larger iron-cross GCP targets with black and white segments and $30 \mathrm{~cm}$ diameter. At some of the sites, the collection of UAV data was impeded by bad weather (wind speeds in excess of $30 \mathrm{~km} \mathrm{hr}^{-1}$ ), therefore some sites were revisited and one additional site was added in the second year of field campaign.

Ground-based photographic surveys

Ground-based photographs were taken at oblique angles around each erosion feature using a Canon 600D SLR 18 mega pixel digital camera with a $28 \mathrm{~mm}$ lens (focal length set to infinity). Camera settings varied based upon light conditions, with exposure between 100 and 400 ISO, aperture between F4.5 and F8 and shutter speed between $1 / 100$ and $1 / 250$ second. Between 20 and 40 GCPs (numbered black markers $\sim 6 \times 8 \mathrm{~cm}$ with a circular white target) were placed around and within 
each feature (Table 3), with co-ordinates measured by RTK DGPS instruments as in the UAV survey.

TLS surveys

The Riegl VZ 1000 terrestrial laser scanner was used to provide an independent reference benchmark measurement. This instrument is capable of measuring targets located up to $1400 \mathrm{~m}$ in range and is co-mounted with a high resolution 12.1 MP digital camera to enable coloured point-clouds. The scanner acquires ca. 122,000 points per second with a typical point cloud has ca. 80 million points per scan. Scans were carried out using an angular resolution of $0.025^{\circ}$ vertically and horizontally and a range maximum of $450 \mathrm{~m}$; resulting in a point spacing of $\sim 4 \mathrm{~mm}$ at 100 m. Typically two scans were taken for each gully feature, except in more complex morphology, where three or more scans were taken, the most complex gullies requiring up to ten scans to reduce shadows. Scan positions were georeferenced using a Leica GS14 differential GNSS connected to the Leica SmartNet network. These corrections were obtained in real-time via a GPRS Internet radio connection, allowing positional accuracies less than $20 \mathrm{~mm}$ in all cases. A reflective target was mounted on a $1 \mathrm{~m}$ pole within the sight of all scans (if this was not possible a second target was used) to identify georeferenced back-sight positions during post-processing. 


\section{Data processing}

Between 150 and 600 images were used to build each high resolution 3D UAV SfM model and between 127 and 987 to build each GP SfM high resolution model using Agisoft Photoscan software v 1.1.5, covering between 2.3 and 18 ha in area for UAV and between 0.01 and 0.1 ha for GP SfM. Models were georeferenced using GCPs. As the smaller GCP targets used in 2014 proved difficult to identify in the captured UAV images, only between 3 and 5 GCPs were registered for model georeferencing. The larger circular iron-cross targets used in 2015 were more easily identified in the captured images and therefore between 6 and 28 GCPs were used for UAV model georeferencing. Between 8 and 36 GCPs were used in GP SfM model reconstructions. The registration error derived from GCPs within Agisoft Photoscan ranged between $0.004 \mathrm{~m}$ and $0.132 \mathrm{~m}$ for the UAV technique and $0.01 \mathrm{~m}$ and $0.29 \mathrm{~m}$ for GP (Table 3). The extremely low error of $0.004 \mathrm{~m}$ in the 2014 UAV survey at Hangingstone Hill may be due to the low number of GCPs included in model reconstruction.

Riegl RiScanPro and MapTek I-Site Studio were used to post-process the TLS data. The point clouds were initially aligned and geo-referenced in RiScanPro, using the GNSS measurements taken at the same time and location of each scan position and any artefacts and false-points were removed. The scans were then coloured, using the RGB data from the digital camera images, and cropped to the area of interest. The scans were exported to I-Site Studio as individual las files where they were run through a series of filtering tools to remove isolated points, vegetation and topographic anomalies, and finally merged into single feature scans. At two heavily 
vegetated sites, ground surface was derived by using open-source LAS-thin tool http://www.cs.unc.edu/ isenburg/lastools/ to filter-off vegetation at a $10 \times 10 \mathrm{~cm}$ resolution.

Point clouds from all three techniques were co-registered in open-source CloudCompare software (http://www.danielgm.net/cc/) using the iterative closest point approach (Besl and McKay, 1992; Chen and Medioni, 1991). The mean raw point cloud density was $2.3 \times 10^{5} \mathrm{~m}^{-2}$ for GP, $1.3 \times 10^{3} \mathrm{~m}^{-2}$ for UAV and $4.8 \times 10^{3} \mathrm{~m}^{-2}$ for TLS. GP and TLS point clouds were sub-sampled to $2 \mathrm{~cm}$ resolution to reduce cloud size, using the mean value within each square domain. This $2 \mathrm{~cm}$ resolution was chosen as a reasonable compromise between dataset size (and hence practicalities in processing) and resolution, when dealing with erosion features with characteristic dimensions of metres to several 10's of metres. Point clouds were manually cropped in CloudCompare to isolate gully features, with the top of the gully wall identified visually and only extreme outlying points, further than $0.5 \mathrm{~m}$ above and below the gully surface, removed. A DEM was created in Surfer v. 12 software, interpolated over the $2 \mathrm{~cm}$ grid. Gully edges were identified visually at each site and a single pre-erosion surface was derived from the TLS reference data by linear interpolation using Surfer v. 12. Pre-erosion surface models were then passed through a low-pass filter to reduce roughness due to elevation variation on gully edges. 


\section{Data analysis}

Volumetric soil loss estimates were quantified from the difference between the DEM and the modelled pre-erosion surface. The same pre-erosion surface was applied to all three techniques for consistency.

Volumetric estimates from the three techniques were compared directly and using linear regression. Appendix 1 summarises the volumetric data used in these comparisons. Volume measurement error was quantified using Eq. 1 as in Castillo et al. (2012):
$\mathrm{Ev}=\frac{(\mathrm{Vp}-\mathrm{Vo})}{\mathrm{Vo}} \times 100$
Eq. 1

Where $E_{v}$ is the relative volume measurement error $(\%), V_{p}$ the observed volume of eroded soil in the gully $\left(\mathrm{m}^{3}\right)$ for each SfM technique, and $V_{0}$ the observed volume of eroded soil for the reference TLS method $\left(\mathrm{m}^{3}\right)$.

Repeat GP SfM DEM's were produced for 13 erosion features at four sites visited in both 2014 and 2015 (Table 4). The two DEMs were differenced using the DEMs of Difference (DOD) approach (Martínez-Casasnovas, 2003), which uses simple subtraction of multi-temporal DEMs, to derive annual erosion rates. Volume survey uncertainty $\left(\mathrm{V}_{\mathrm{e}}\right)$ was calculated as the product of the standardised DGPS measurement error $(E=0.03 \mathrm{~m})$ and the cropped gully area $(A)$ :

$$
V e=\mathrm{E} * \mathrm{~A}
$$

Eq. 2 
This method was chosen in preference to more sophisticated error propagation techniques (Brasington et al., 2003; Lane et al., 2003) as it was deemed most suitable for a project aimed at testing of practical technique application at a national scale.

Cost-effectiveness of the three techniques was compared by recording the amount of time spent in the field on an initial walk over survey, site marking (including placing of GCPs), field surveying and data post-processing (including data cleaning, georeferencing, DEM elaboration). Computer CPU time for data post-processing was also recorded (Table 5).

\section{Results and discussion}

\section{Accuracy of techniques}

We compared the datasets directly and using linear regression. The linear regression revealed that volumetric soil loss estimates derived from the three techniques were closely related $\left(R^{2}=0.99, p<0.001\right)$. For the comparison between GP and TLS, the intercept was significantly different from $0(6.55, \mathrm{p}<0.05)$ and slope equalled $0.99(p<0.001)$ (Fig 3a). For the comparison between UAV and TLS measurements, the intercept was near-zero (10.01, n.s.) and slope equalled 1.01 $(p<0.001)$ (Fig. 3b). For the comparison between GP and UAV, the intercept was near zero $(-1.65, n . s$.$) and slope equalled 1.03(p<0.001)$ (Fig 3c). The mean ratio between UAV and TLS gully volume estimates was $0.89(n=19, S D=0.18)$ and 
between GP and TLS it was $0.97(n=39, S D=0.09)$ (Fig. 4). These ratios suggest that while for GP, the ratio is consistent across the survey range, the UAV seems to underestimate the volumes of smaller features, most likely due to the reduced line of sight in respect of very small features (Fig. 4).

Despite approximately five-fold difference in mean observation distances between UAV $(28 \mathrm{~m})$ and GP $(5 \mathrm{~m}) \mathrm{SfM}$, these techniques produced comparable vertical errors (UAV $0.05-0.35$ m vs GP $0.03-0.32$ (Table 3). While, at the higher end, these errors exceeded the RMSE range of $0.01-0.1 \mathrm{~m}$ found by Smith et al. (2015) who reviewed published point to raster, raster to raster and point to point comparisons of SfM surveys made over similar observation distances, they were comparable with decimetre-level vertical accuracies for UAV derived DEMs of 0.29 m (Hugenholtz et al., 2013), 0.14 m (Ouédraogo et al., 2014) and $0.52 \mathrm{~m}$ in upland vegetated areas and $0.20 \mathrm{~m}$ in less densely vegetated areas (Tonkin et al., 2014) and comparable with ALS accuracy of 0.19-0.23 m (Hodgson and Bresnahan, 2004), $0.29 \mathrm{~m}$ (Hugenholtz et al., 2013), $0.08 \mathrm{~m}$ (Toth et al., 2007). For GP-derived DEMs, the vertical accuracies found in this study $(0.03-0.32 \mathrm{~m})$ were on the whole less accurate than those previously reported in the literature (0.004-0.008 $\mathrm{m}$ (Eltner et al., 2014), 0.009-0.025 m (Gómez-Gutiérrez et al., 2014), 0.155 m (Frankl et al., 2015)).

GP showed a smaller mean relative error in volume estimation than UAV (mean 3.15 vs $-11.18 \%$, SD 9.15 vs 17.78 ). This is similar to the $-3.1 \%$ volume estimation error previously reported for GP SfM (Castillo et al., 2012). Conversely, the UAV 
technique showed greatest volumetric errors for the smallest gullies, with a maximum volume under-estimation of $-49 \%$ (Figure 4$)$.

\section{Evaluating annual erosion rates}

Figures $2 \mathrm{~b}$ and 5 show an example coloured point cloud and DOD for one of the 11 erosion features with repeated surveys (Table 4). At this heavily eroded site, the vegetation changes dominate the DOD and thus obscure the erosional evidence when the full area is taken into account. Therefore, the difference maps were cropped to include only the bare ground within the eroding gullies and elevation differences of $\pm 0.03 \mathrm{~m}$, regarded as the effective accuracy of the survey methods, were plotted as zero. Table 4 shows the results from all repeat surveys.

Figure 6 shows that erosion was detected at most sites, with the exception of two features at Southern Scar. The Southern Scar sites were distinct in that they were largely mineral-floored gullies and, in contrast to peat-floored gullies at the other sites, are expected to erode more slowly. The average recorded vertical erosion rate among all sites was $0.033 \mathrm{~m} \mathrm{a}^{-1}$. Separating the mineral-floored Southern Scar sites from the peat-floored sites gave average vertical erosion rates of $0.077 \mathrm{~m} \mathrm{a}^{-1}$ for the peat-floored gully systems. The perceived mean aggradation of $0.011 \mathrm{~m} \mathrm{a}^{-1}$ for the mineral-floored system at Southern Scar was within the $\pm 0.03 \mathrm{~m}$ estimated accuracy of the technique and therefore not distinguishable from zero. As the annual differences in vertical measurements were close to the resolution of the techniques, longer than annual resurvey might be preferable for monitoring of upland soil erosion, particularly on mineral soils. 
Previous estimates of erosion rates on bare peat surfaces were largely derived from erosion pin data on gully walls. Evans and Warburton (2008) tabulated mean erosion rates reported from bare peat surfaces across the globe of $0.024 \pm 0.008 \mathrm{~m}$ $\mathrm{a}^{-1}$. The average erosion rates recorded in this study at peat-floored systems were around three times higher, most likely due to gully floor areas being subject to erosion by running water as well as rainsplash and wind erosion processes dominating on gully walls. As the values recorded herein included some areas of gully wall with lower erosion rates, the mean erosion rates reported here represent minimum estimated vertical erosion on gully floors.

The annual erosion rates recorded in this study represent the first systematic measurements of erosion rates in peat-floored gullies incorporating the impact of flowing water on gully floors. These high annual erosion rates have implications for particulate carbon loss from extensive peat-floored gully systems, typically present in areas of relatively recent onset of erosion, and imply that carbon fluxes from eroding peatlands may be higher in the early stages of erosion.

The ability to detect change from repeat SfM surveys is limited by the rate of observed erosion and the achievable resolution of the survey technique. In this study, some of the largest observed rates of change were observed at the edges of gully features. While these may represent localised mass failures of gully walls, in some cases patterns of apparent erosion and deposition observed on both sides of a gully suggest that the change is likely due to geo-referencing errors. Therefore, wherever possible, permanent ground control should be used for repeat SfM surveys to minimise measurement error and GCP deployment should be carefully considered 
within the initial survey design in order to deliver the overall precision, accuracy and spatial resolution required of the final DEM. GCP deployment can be guided by conventional aerial survey design (e.g. Abdullah et al., 2013) for UAV surveys, but requires more site-specific considerations for ground-based image collection. Nevertheless, in both cases, the achieved performance of the network and of individual GCPs can be assessed in detail through Monte Carlo approaches (James et al., 2017). Finally, other potential errors may relate to potential shrinkage and swelling of peat surfaces. In gully systems these effects can be significant where associated with the formation of needle ice (Evans and Warburton, 2007). Therefore measurement campaigns should be planned to avoid periods of frost, as was the case in this study. Moisture related changes on relatively dry gully edges are regarded as minor, relative to the scale of the observed recession, but may contribute to measurement noise in short-term measurements.

This study included widely spaced, but limited number of sites across England and Wales. These first measurements of 'whole gully' erosion rates in peat areas are a useful addition to our empirical knowledge of these systems and indicate the new scientific insights that could be derived from a wider national soil erosion survey. For visible erosion features, such as rills or gullies, such an approach, undertaken every year could provide an excellent basis for monitoring of annual soil erosion rates. However, increasing the survey interval to every three or five years would maximise the potential for change detection in areas with relatively low erosion rates, minimise relative error associated with vegetation cover and surface heave and increase the cost-effectiveness of re-survey. 


\section{Areal versus volumetric change}

The SfM modelling approach described above produces high resolution estimates of vertical erosion, as well as volumetric erosion estimates, which can be interpreted as true material fluxes from the landscape. As such they have particular value in assessing the impact of erosion on biogeochemical cycling and off-site impacts. While upland erosion rates are strongly controlled by the presence or absence of vegetation, volumetric erosion estimates are able to demonstrate change in rates of bare ground erosion.

The SfM approach developed and trialled herein provides high resolution data for relatively small features $(<0.1 \mathrm{ha})$. In order to understand the true extent of upland soil erosion, it is necessary to upscale these measurements to larger areas. However, areal estimates of percentage bare ground cannot substitute volumetric measurement in erosion monitoring as hydroclimatic trends under climate change scenarios may affect erosion rates from existing areas of bare ground without necessarily leading to an expansion of the un-vegetated area. An effective monitoring scheme for upland soil erosion should therefore combine both areal and volumetric measurement of erosion rates, using UAV SfM for this upscaling. 


\section{$\underline{\text { Cost-effectiveness }}$}

In terms of field data capture, on a per-site basis the cost, in person-hours, of GP was less than TLS and less than UAV but on an areal basis TLS was cheaper than UAV and than GP. UAV and TLS processing times were comparable and significantly less than GP particularly for large areas (see table 5). This was due to the small photo footprint and the greater photo density derived from GP. Both SfM techniques were much less costly than TLS; UAV representing only $1.5 \%$ and GP representing only $0.8 \%$ of the TLS software and equipment costs.

Several practical lessons were learnt from this pilot study. Firstly, it is important to allow sufficient time for training personnel in the use of these techniques. We estimate that about three months of full-time effort are required before the SfMbased photographic techniques can be deployed in the field with confidence, in a variety of weather conditions. This includes training in taking high quality photographs both from UAV and GP, an appreciation of the number of photos required for reconstruction of accurate models, an ability to operate the UAV and DGPS with confidence in unpredictable weather conditions, troubleshoot technical problems and deploy suitable GCP markers that can be clearly identified in the resulting images. Secondly, the remoteness of locations and prevailing weather conditions in upland areas present a challenge so field survey at our study sites was largely restricted to the summer months when visibility and wind conditions were optimal. Here, the ground-based photographic techniques have an advantage over the TLS, which weighs $\sim 18 \mathrm{~kg}$. Although the SFM as the equipment was more 
lightweight and portable, it was still necessary to carry DGPS equipment, which weighs $\sim 15 \mathrm{~kg}$.

\section{Conclusions}

This research compared three remote sensing techniques - terrestrial laser scanning and 3D surface reconstructions from ground based and aerial photography - for estimating volumetric soil loss due to soil erosion in upland landscapes. There was a close correlation between the two photographic techniques, both of which performed well when compared to TLS as a benchmark. The UAV costeffectiveness compared favourably with the other two techniques on a per-hectare basis, for areas $>0.2$ ha, and appears to be most suitable for monitoring of extensive visible soil erosion features, although high wind speeds and mist may be limiting its deployment in adverse weather conditions. Ground-based photography was most cost-effective for plot-scale surveying of smaller areas with intricate erosion features, in a range of terrains and weather conditions; however it was not cost-effective for deployment over large survey areas. Ground-based photography was the cheapest in terms of equipment costs, while UAV-based photography was more efficient in terms of data post-processing time. Although combining 3D models derived from both UAV and ground-based photography was beyond the scope of this study, further research should explore the cost effectiveness of this combined approach and whether it would yield significant improvements in the accuracy of volumetric estimates for intricate soil erosion features. The photographic techniques were capable of detecting change from annual repeat surveys on peaty soils in these dynamic landscapes and thus elucidate the rates and processes of upland gully 
erosion. The data from the study suggest that gully erosion rates from bare peat surfaces exceed previous estimates because of the ability for aerially extensive measurements to integrate localised erosion by running water as well as more extensive rainsplash and wind erosion.

\section{Acknowledgements}

This research was funded by and carried out under the UK Department for Environment, Food and Rural Affairs project SP1311 'Piloting a cost-effective framework for monitoring soil erosion in England and Wales'. We would like to thank two anonymous referees for their informative comments that helped to improve this manuscript.

\section{References}

Abdullah, Q., Bethel, J., Hussain, M., Munjy R. 2013. Photogrammetric project and mission planning. In Manual of Photogrammetry, McGlone JC (ed). Americal Society for Photogrammetry and Remote Sensing; 1187-1220.

Bower, MM. 1961. The distribution of erosion in blanket peat bogs in the Pennines. Transactions and Papers (Institute of British Geographers), (29), pp.17-30.

Brazier, R.E., Anderson, K., Benaud, P., Evans, M., Farrow, L., Glendell, M., James, M., Lark, M., Quine, T., Quinton, J., Rawlins, B., Rickson, R. (2016) Final report to Defra - SP1311 - Developing a cost-effective framework to monitor soil erosion in England and Wales. 
Besl P, McKay N. 1992. A Method for Registration of 3-D Shapes. IEEE

Transactions on Pattern Analysis and Machine Intelligence 14 : 239-256. DOI:

$10.1109 / 34.121791$

Brasington J, Langham J, Rumsby B. 2003. Methodological sensitivity of morphometric estimates of coarse fluvial sediment transport. Geomorphology 53 : 299-316. DOI: 10.1016/S0169-555X(02)00320-3

Castillo C, Pérez R, James MR, Quinton JN, Taguas E V., Gómez J a. 2012. Comparing the Accuracy of Several Field Methods for Measuring Gully Erosion. Soil Science Society of America Journal 76 : 1319. DOI: 10.2136/sssaj2011.0390

Cazorzi F, Fontana GD, Luca A De, Sofia G, Tarolli P. 2013. Drainage network detection and assessment of network storage capacity in agrarian landscape. Hydrological Processes 27 : 541-553. DOI: 10.1002/hyp.9224

Chen Y, Medioni G. 1991. Object modeling by registration of multiple range images. Proceedings. 1991 IEEE International Conference on Robotics and Automation : 2724-2729. DOI: 10.1109/ROBOT.1991.132043

Cunliffe AM, Brazier RE, Anderson K. 2016. Remote Sensing of Environment Ultra- fi ne grain landscape-scale quanti fi cation of dryland vegetation structure with droneacquired structure-from-motion photogrammetry. Remote Sensing of Environment 183 : 129-143. DOI: 10.1016/j.rse.2016.05.019 
Eltner A, Baumgart P, Maas H-G, Faust D. 2014. Multi-temporal UAV data for automatic measurement of rill and interrill erosion on loess soil. Earth Surface

Processes and Landforms : 741-755. DOI: 10.1002/esp.3673

Evans, Martin; Warburton J. 2007. Geomorphology of Upland Peat: Erosion, Form and Landscape Change. WILEY-BLACKWELL: Oxford

Evans M, Lindsay J. 2010a. High resolution quantification of gully erosion in upland peatlands at the landscape scale. Earth Surface Processes and Landforms 35 : 876 886. DOI: $10.1002 /$ esp. 1918

Evans M, Lindsay J. 2010b. Impact of gully erosion on carbon sequestration in blanket peatlands. Climate Research 45 : 31-41. DOI: 10.3354/cr00887

Frankl A, Stal C, Abraha A, Nyssen J, Rieke-Zapp D, De Wulf A, Poesen J. 2015. Detailed recording of gully morphology in 3D through image-based modelling. Catena 127 : 92-101. DOI: 10.1016/j.catena.2014.12.016

Gómez-Gutiérrez Á, Schnabel S, Berenguer-Sempere F, Lavado-Contador F, RubioDelgado J. 2014. Using 3D photo-reconstruction methods to estimate gully headcut erosion. Catena 120 : 91-101. DOI: 10.1016/j.catena.2014.04.004

Grand-Clement E, Anderson K, Smith D, Luscombe D, Gatis N, Ross M, Brazier RE. 2013. Evaluating ecosystem goods and services after restoration of marginal upland peatlands in South-West England. Wan S (ed). Journal of Applied Ecology 50 : 324- 
Gregory a. S et al. 2015. A review of the impacts of degradation threats on soil properties in the UK. Soil Use and Management 31 : 1-15. DOI: 10.1111/sum.12212

Hilley GE, Arrowsmith JR. 2008. Geomorphic response to uplift along the Dragon's Back pressure ridge, Carrizo Plain, California. Geology 36 : 367-370. DOI: 10.1130/G24517A.1

Hodgson ME, Bresnahan P. 2004. Accuracy of Airborne Lidar-Derived Elevation: Empirical Assessment and Error Budget. Photogrammetric engineering and remote sensing 70 : 331-339. DOI: 10.14358/PERS.70.3.331

Hugenholtz CH, Walker J, Brown O, Myshak S. 2015. Earthwork Volumetrics with an Unmanned Aerial Vehicle and Softcopy Photogrammetry. Journal of Surveying Engineering 141 : 06014003. DOI: 10.1061/(ASCE)SU.1943-5428.0000138

Hugenholtz CH, Whitehead K, Brown OW, Barchyn TE, Moorman BJ, LeClair A, Riddell K, Hamilton T. 2013. Geomorphological mapping with a small unmanned aircraft system (sUAS): Feature detection and accuracy assessment of a photogrammetrically-derived digital terrain model. Geomorphology 194 : 16-24. DOI: 10.1016/j.geomorph.2013.03.023

Jaboyedoff, M.; Oppikofer, T.; Abellan, A.; Derron, M.-H.; Loye, A.; Metzger, R.; Pedrazzini A, Jaboyedoff M, Oppikofer T, Abell??n A, Derron MH, Loye A, Metzger 
R, Pedrazzini A. 2012. Use of LIDAR in landslide investigations: A review. Natural Hazards 61 :5-28. DOI: 10.1007/s11069-010-9634-2

James, M.R., Robson, S., d'Oleire-Oltmanns, S. and Niethammer U. 2017.

Optimising UAV topographic surveys processed with structure-from-motion: Ground control quality, quantity and bundle adjustment. Geomorphology 280 : 51-66. DOI:

10.1016/j.geomorph.2016.11.021

James MR, Pinkerton H, Applegarth LJ. 2009. Detecting the development of active lava flow fields with a very-long-range terrestrial laser scanner and thermal imagery. Geophysical Research Letters 36 : 10-14. DOI: 10.1029/2009GL040701

James MR, Quinton JN. 2014. Ultra-rapid topographic surveying for complex environments: The hand-held mobile laser scanner (HMLS). Earth Surface Processes and Landforms 39 : 138-142. DOI: 10.1002/esp.3489

James MR, Robson S. 2012. Straightforward reconstruction of 3D surfaces and topography with a camera: Accuracy and geoscience application. Journal of Geophysical Research: Earth Surface 117 : 1-17. DOI: 10.1029/2011JF002289

Javernick L, Brasington J, Caruso B. 2014. Modeling the topography of shallow braided rivers using Structure-from-Motion photogrammetry. Geomorphology 213 : 166-182. DOI: 10.1016/j.geomorph.2014.01.006

Johnson K, Nissen E, Saripalli S, Arrowsmith JR, McGarey P, Scharer K, Williams P, 
Blisniuk K. 2014. Rapid mapping of ultrafine fault zone topography with structure from motion. Geosphere 10 : 969-986. DOI: 10.1130/GES01017.1

Kereszturi G, Procter J, Cronin SJ, N??meth K, Bebbington M, Lindsay J. 2012. LiDAR-based quantification of lava flow susceptibility in the City of Auckland (New Zealand). Remote Sensing of Environment 125 : 198-213. DOI:

10.1016/j.rse.2012.07.015

Lane SN, Westaway RM, Hicks DM. 2003. Estimation of erosion and deposition volumes in a large, gravel-bed, braided river using synoptic remote sensing. Earth Surface Processes and Landforms 28 : 249-271. DOI: 10.1002/esp.483

Legleiter CJ. 2012. Remote measurement of river morphology via fusion of LiDAR topography and spectrally based bathymetry. Earth Surface Processes and Landforms 37 : 499-518. DOI: 10.1002/esp.2262

Lucieer a., Jong SMD, Turner D. 2014. Mapping landslide displacements using Structure from Motion (SfM) and image correlation of multi-temporal UAV photography. Progress in Physical Geography 38 : 97-116. DOI: $10.1177 / 0309133313515293$

Martínez-Casasnovas JA. 2003. A spatial information technology approach for the mapping and quantification of gully erosion. Catena 50 : 293-308. DOI:

10.1016/S0341-8162(02)00134-0 
McHugh M. 2007. Short-term changes in upland soil erosion in England and Wales: 1999 to 2002. Geomorphology 86 : 204-213. DOI: 10.1016/j.geomorph.2006.06.010

Ouédraogo MM, Degré A, Debouche C, Lisein J. 2014. The evaluation of unmanned aerial system-based photogrammetry and terrestrial laser scanning to generate DEMs of agricultural watersheds. Geomorphology $214: 339-355$. DOI:

10.1016/j.geomorph.2014.02.016

Passalacqua $P$ et al. 2015. Analyzing high resolution topography for advancing the understanding of mass and energy transfer through landscapes: A review. EarthScience Reviews 148 : 174-193. DOI: 10.1016/j.earscirev.2015.05.012

Passalacqua P, Tarolli P, Foufoula-Georgiou E. 2010. Testing space-scale methodologies for automatic geomorphic feature extraction from lidar in a complex mountainous landscape. Water Resources Research 46 : 1-17. DOI:

10.1029/2009WR008812

Smith MW, Carrivick JL, Hooke J, Kirkby MJ. 2014. Reconstructing flash flood magnitudes using "Structure-from-Motion": A rapid assessment tool. Journal of Hydrology 519 : 1914-1927. DOI: 10.1016/j.jhydrol.2014.09.078

Smith MW, Carrivick JL, Quincey DJ. 2015. Structure from motion photogrammetry in physical geography. Progress in Physical Geography DOI:

$10.1177 / 0309133315615805$ 
Smith MW, Vericat D. 2015. From experimental plots to experimental landscapes: topography, erosion and deposition in sub-humid badlands from Structure-fromMotion photogrammetry. Earth Surface Processes and Landforms 40 : 1656-1671. DOI: $10.1002 /$ esp.3747

Snapir B, Hobbs S, Waine TW. 2014. Roughness measurements over an agricultural soil surface with Structure from Motion. ISPRS Journal of Photogrammetry and Remote Sensing 96 : 210-223. DOI: 10.1016/j.isprsjprs.2014.07.010

Sofia G, Fontana GD, Tarolli P. 2014. High-resolution topography and anthropogenic feature extraction: Testing geomorphometric parameters in floodplains. Hydrological Processes 28 : 2046-2061. DOI: 10.1002/hyp.9727

Sofia G, Tarolli P, Cazorzi F, Dalla Fontana G. 2011. An objective approach for feature extraction: Distribution analysis and statistical descriptors for scale choice and channel network identification. Hydrology and Earth System Sciences 15 : 1387-1402. DOI: 10.5194/hess-15-1387-2011

Stumpf a., Malet J-P, Allemand P, Pierrot-Deseilligny M, Skupinski G. 2015. Ground-based multi-view photogrammetry for the monitoring of landslide deformation and erosion. Geomorphology 231 : 130-145. DOI:

10.1016/j.geomorph.2014.10.039

Tarolli P. 2014. High-resolution topography for understanding Earth surface processes: Opportunities and challenges. Geomorphology 216 : 295-312. DOI: 
10.1016/j.geomorph.2014.03.008

Tonkin TN, Midgley NG, Graham DJ, Labadz JC. 2014. The potential of small unmanned aircraft systems and structure-from-motion for topographic surveys: A test of emerging integrated approaches at Cwm Idwal, North Wales. Geomorphology 226 :35-43. DOI: 10.1016/j.geomorph.2014.07.021

Toth C, Brzezinska D, Csanyi N, Paska E, Yastikli N. 2007. LiDaR mapping supporting earthquake research of the San Andreas fault. ASPRS 2007 Annual Conference, Tampa, Florida : 1-11.

Turner D, Lucieer A, de Jong S. 2015. Time Series Analysis of Landslide Dynamics Using an Unmanned Aerial Vehicle (UAV). Remote Sensing 7 : 1736-1757. DOI: 10.3390/rs70201736 [online] Available from: http://www.mdpi.com/2072$4292 / 7 / 2 / 1736 /$

Verheijen FG a, Jones RJ a, Rickson RJ, Smith CJ, Bastos a C, Nunes JP, Keizer JJ. 2012. Concise overview of European soil erosion research and evaluation. Acta Agriculturae Scandinavica: Section B, Soil \& Plant Science 62 : 185-190. DOI: $10.1080 / 09064710.2012 .697573$

Warburton J, Evans MG, Johnson RM. 2003. Discussion on "The extent of soil erosion in Upland England and Wales." Earth Surface Processes and Landforms 28 : 219-223. DOI: 10.1002/esp.477 
Westoby MJ, Brasington J, Glasser NF, Hambrey MJ, Reynolds JM. 2012.

"Structure-from-Motion" photogrammetry: A low-cost, effective tool for geoscience applications. Geomorphology 179 : 300-314. DOI: 10.1016/j.geomorph.2012.08.021

Williams RD, Brasington J, Vericat D, Hicks DM. 2014. Hyperscale terrain modelling of braided rivers: Fusing mobile terrestrial laser scanning and optical bathymetric mapping. Earth Surface Processes and Landforms 39 : 167-183. DOI:

10.1002/esp.3437

Williams RD, Rennie CD, Brasington J, Hicks DM, Vericat D. 2015. Linking the spatial distribution of bed load transport to morphological change during high-flow events in a shallow braided river. Journal of Geophysical Research : Earth Surface : 604-622. DOI: 10.1002/2014JF003346.Received

Woodget a. S, Carbonneau PE, Visser F, Maddock IP. 2015. Quantifying submerged fluvial topography using hyperspatial resolution UAS imagery and structure from motion photogrammetry. Earth Surface Processes and Landforms 40 : 47-64. DOI: 10.1002/esp.3613 
Table 1. Location and soil characteristics of the 10 study locations. *Based on Cranfield University (2015) The Soils Guide. Available: www.landis.org.uk. Cranfield University, UK. Accessed 30/10/2015

\begin{tabular}{|c|c|c|c|c|c|}
\hline Site name & Latitude & Longitude & $\begin{array}{l}\text { World } \\
\text { Reference Base } \\
\text { soil } \\
\text { classification* }\end{array}$ & $\begin{array}{l}\text { Erosion } \\
\text { feature } \\
\text { (Bower, } \\
1961)\end{array}$ & $\begin{array}{l}\text { Survey } \\
\text { extent } \\
\mathrm{km}^{2}\end{array}$ \\
\hline Forest of Bowland & $53^{\circ} 57^{\prime} 08.74^{\prime \prime} \mathrm{N}$ & $002^{\circ} 38^{\prime} 09.36^{\prime \prime} \mathrm{W}$ & $\begin{array}{l}\text { Stagnosol and } \\
\text { histosol }\end{array}$ & $\begin{array}{l}\text { Type } 1 \\
\text { gullies }\end{array}$ & 0.04 \\
\hline Howgill Fells & $54^{\circ} 25^{\prime} 14.55^{\prime \prime} \mathrm{N}$ & $002^{\circ} 30^{\prime} 16.40^{\prime \prime} \mathrm{W}$ & $\begin{array}{l}\text { Umbrisol, } \\
\text { podzol and } \\
\text { stagnosol }\end{array}$ & $\begin{array}{l}\text { Shallow } \\
\text { landslides }\end{array}$ & 0.03 \\
\hline Waur & $51^{\circ} 57^{\prime} 45.97^{\prime \prime} \mathrm{N}$ & $003^{\circ} 08^{\prime} 35.49^{\prime \prime} \mathrm{W}$ & Histosol & $\begin{array}{l}\text { Plateaux } \\
\text { erosion }\end{array}$ & 0.03 \\
\hline Southern Scar & $51^{\circ} 59^{\prime} 57.72^{\prime \prime} \mathrm{N}$ & $003^{\circ} 04^{\prime} 48.21^{\prime \prime} \mathrm{W}$ & Histosol & $\begin{array}{l}\text { Eroded to } \\
\text { mineral } \\
\text { ground }\end{array}$ & 0.02 \\
\hline Upper North Grain & $53^{\circ} 26^{\prime} 31.43^{\prime \prime} \mathrm{N}$ & $001^{\circ} 50^{\prime} 07.00^{\prime \prime} \mathrm{W}$ & $\begin{array}{l}\text { Podzol and } \\
\text { histosol }\end{array}$ & $\begin{array}{l}\text { Type } 1 \text { and } 2 \\
\text { gullies }\end{array}$ & 0.04 \\
\hline Hangingstone Hill & $50^{\circ} 39^{\prime} 19.45^{\prime \prime N}$ & $003^{\circ} 57^{\prime 28.35 " W}$ & Histosol & $\begin{array}{l}\text { Revegetated } \\
\text { Type } 1 \\
\text { gullies and } \\
\text { peat hags }\end{array}$ & 0.18 \\
\hline Moorhouse & $54^{\circ} 41^{\prime} 03.32^{\prime \prime} \mathrm{N}$ & $002^{\circ} 22^{\prime} 16.32^{\prime \prime} \mathrm{W}$ & Histosol & $\begin{array}{l}\text { Re-vegetated } \\
\text { Type } 1 \\
\text { gullies }\end{array}$ & 0.07 \\
\hline Migneint 1 & $52^{\circ} 58^{\prime} 05.25^{\prime \prime} \mathrm{N}$ & $003^{\circ} 50^{\prime 24.13 " \mathrm{~W}}$ & Histosol & $\begin{array}{l}\text { Eroded but } \\
\text { recovering } \\
\text { pool and } \\
\text { hummock } \\
\text { system }\end{array}$ & 0.05 \\
\hline Migneint 2 & $52^{\circ} 59^{\prime} 24.57^{\prime \prime} \mathrm{N}$ & $003^{\circ} 48^{\prime} 35.56 " \mathrm{~W}$ & Histosol & Type 1 gully & 0.04 \\
\hline Nateby Moor & $54^{\circ} 26^{\prime} 14.09^{\prime \prime} \mathrm{N}$ & $002^{\circ} 17^{\prime} 38.14^{\prime \prime} \mathrm{W}$ & Histosol & $\begin{array}{l}\text { Type } 1 \text { and } 2 \\
\text { gullies, peat } \\
\text { hags }\end{array}$ & 0.02 \\
\hline
\end{tabular}


Table 2 Camera settings and acquisition characteristics for UAV SfM surveys.

\begin{tabular}{|c|c|c|c|c|c|c|c|c|c|c|}
\hline $\begin{array}{l}\text { Site and } \\
\text { feature }\end{array}$ & $\begin{array}{l}\text { Surv } \\
\text { ey } \\
\text { year }\end{array}$ & Camera & $\begin{array}{l}\mathrm{IS} \\
\mathrm{O}\end{array}$ & $\begin{array}{l}\text { F- } \\
\text { sto } \\
p\end{array}$ & $\begin{array}{c}\text { Expos } \\
\text { ure } \\
\text { time } \\
\text { (s) }\end{array}$ & $\begin{array}{c}\text { Fly } \\
\text { heig } \\
\text { ht } \\
(\mathrm{m})\end{array}$ & $\begin{array}{c}\text { Foc } \\
\text { al } \\
\text { leng } \\
\text { th } \\
(\mathrm{mm} \\
)\end{array}$ & $\begin{array}{l}\text { Fly } \\
\text { spe } \\
\text { ed } \\
(\mathrm{m} \\
\left.\mathrm{s}^{-1}\right)\end{array}$ & $\begin{array}{l}\text { Phot } \\
\text { o } \\
\text { interv } \\
\text { al (s) }\end{array}$ & $\begin{array}{c}\text { Pix } \\
\text { el } \\
\text { size } \\
(\mathrm{m} \\
\mathrm{m})\end{array}$ \\
\hline $\begin{array}{l}\text { Forest of } \\
\text { Bowland }\end{array}$ & 2015 & Canon SX260 HS & $\begin{array}{c}125 \\
0- \\
160 \\
0\end{array}$ & $\begin{array}{l}5.6 \\
-8\end{array}$ & $\begin{array}{c}1 / 1250 \\
- \\
1 / 1600\end{array}$ & 28 & 4 & 2.0 & 2.5 & 8 \\
\hline $\begin{array}{l}\text { Waun } \\
\text { Fach }\end{array}$ & 2015 & $\begin{array}{l}\text { Canon PowerShot } \\
\text { A2500 }\end{array}$ & 400 & 2.8 & $1 / 2000$ & 25 & 5 & 2.0 & 2.5 & 6 \\
\hline $\begin{array}{l}\text { Southern } \\
\text { Scar }\end{array}$ & 2015 & $\begin{array}{l}\text { Canon PowerShot } \\
\text { A2500 }\end{array}$ & 400 & 2.8 & $1 / 2000$ & 23 & 5 & 2.0 & 2.5 & 5 \\
\hline $\begin{array}{l}\text { Upper } \\
\text { North } \\
\text { Grain }\end{array}$ & 2014 & $\begin{array}{c}\text { Canon PowerShot } \\
\text { A2500 }\end{array}$ & 100 & 2.8 & $1 / 1250$ & 26 & 5 & 2.5 & 3 & 6 \\
\hline $\begin{array}{l}\text { Hangingst } \\
\text { one Hill }\end{array}$ & 2014 & $\begin{array}{c}\text { Canon PowerShot } \\
\text { A2500 }\end{array}$ & $\begin{array}{c}100 \\
- \\
200 \\
\end{array}$ & 2.8 & $\begin{array}{c}1 / 1250 \\
- \\
1 / 1600\end{array}$ & 40 & 5 & 2.5 & 3 & 10 \\
\hline $\begin{array}{l}\text { Moorhous } \\
\text { e }\end{array}$ & 2014 & $\begin{array}{c}\text { Canon PowerShot } \\
\text { A2500 }\end{array}$ & 100 & 2.8 & $1 / 1250$ & 27 & 5 & 2.5 & 3 & 6 \\
\hline Migneint 1 & 2015 & $\begin{array}{c}\text { Canon PowerShot } \\
\text { A2500 }\end{array}$ & 400 & 2.8 & $1 / 2000$ & 23 & 5 & 2.0 & 2.5 & 6 \\
\hline Migneint 2 & 2015 & $\begin{array}{c}\text { Canon PowerShot } \\
\text { Sx260 HS }\end{array}$ & 800 & 7.1 & $1 / 2000$ & 23 & 4 & 2.0 & 2.5 & 7 \\
\hline $\begin{array}{l}\text { Howgill } \\
\text { Fells }\end{array}$ & 2015 & Canon SX260 HS & 400 & 8 & $1 / 1600$ & 44 & 4 & 2.0 & 2.5 & 11 \\
\hline $\begin{array}{l}\text { Nateby } \\
\text { Moor }\end{array}$ & 2015 & Canon SX260 HS & $\begin{array}{c}125 \\
0\end{array}$ & 8 & $1 / 1600$ & 24 & 4 & 2.0 & 2.5 & 7 \\
\hline
\end{tabular}


Table 3 RMSE of the DEMs of difference between GP-based SfM and TLS and between UAV-based SfM and TLS at the scale of gully features.

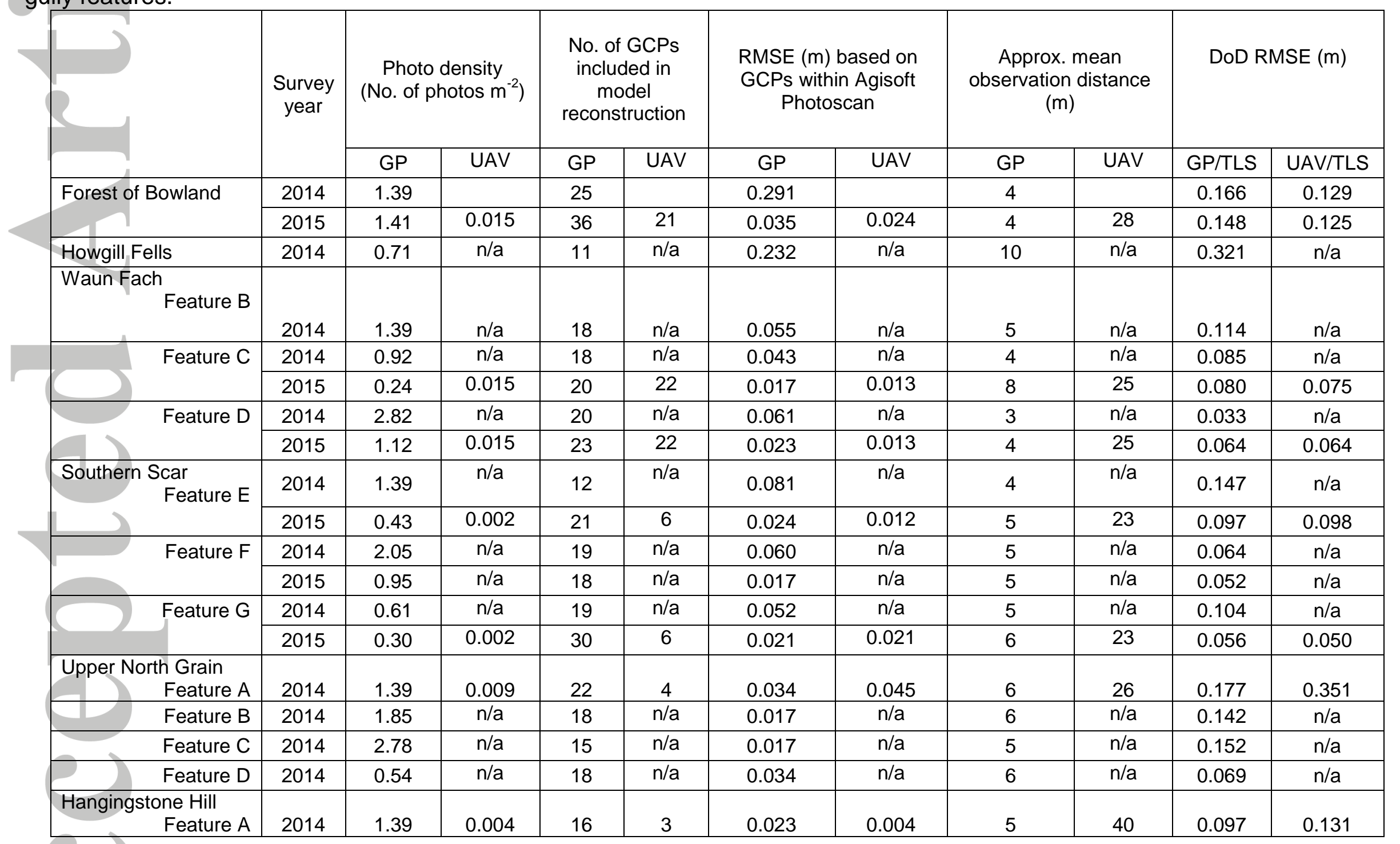

This article is protected by copyright. All rights reserved. 


\begin{tabular}{|c|c|c|c|c|c|c|c|c|c|c|c|c|}
\hline \multirow{2}{*}{\multicolumn{2}{|c|}{ 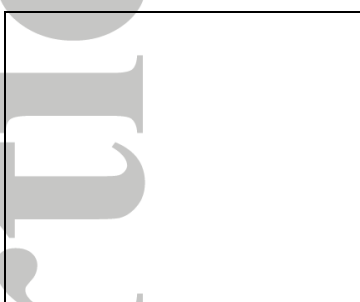 }} & \multirow[t]{2}{*}{$\begin{array}{l}\text { Survey } \\
\text { year }\end{array}$} & \multicolumn{2}{|c|}{$\begin{array}{c}\text { Photo density } \\
\text { (No. of photos } \mathrm{m}^{-2} \text { ) }\end{array}$} & \multicolumn{2}{|c|}{$\begin{array}{l}\text { No. of GCPs } \\
\text { included in } \\
\text { model } \\
\text { reconstruction }\end{array}$} & \multicolumn{2}{|c|}{$\begin{array}{l}\text { RMSE }(m) \text { based on } \\
\text { GCPs within Agisoft } \\
\text { Photoscan }\end{array}$} & \multicolumn{2}{|c|}{$\begin{array}{l}\text { Approx. mean } \\
\text { observation distance } \\
(\mathrm{m})\end{array}$} & \multicolumn{2}{|c|}{ DoD RMSE (m) } \\
\hline & & & GP & UAV & GP & UAV & GP & UAV & GP & UAV & $\overline{G P / T L S}$ & UAV/TLS \\
\hline & Feature $B$ & 2014 & 1.77 & 0.004 & 12 & 3 & 0.083 & 0.004 & 5 & 40 & 0.124 & 0.117 \\
\hline & Feature $\mathrm{C}$ & 2014 & 1.92 & 0.004 & 28 & 3 & 0.018 & 0.004 & 7 & 40 & 0.144 & 0.167 \\
\hline \multicolumn{13}{|c|}{ Moorhouse } \\
\hline & Feature $\mathrm{A}$ & 2014 & 1.39 & 0.007 & 8 & 5 & 0.037 & $0.1 ` 32$ & 8 & 27 & 0.190 & 0.103 \\
\hline & Feature $B$ & 2014 & 1.12 & 0.007 & 31 & 5 & 0.202 & 0.132 & 7 & 27 & 0.106 & 0.085 \\
\hline & Feature $\mathrm{C}$ & 2014 & 1.17 & 0.007 & 20 & 5 & 0.025 & 0.132 & 8 & 27 & 0.088 & 0.096 \\
\hline Mignein & \multirow{2}{*}{ Feature $A$} & 2014 & 1.39 & $\mathrm{n} / \mathrm{a}$ & 22 & $\mathrm{n} / \mathrm{a}$ & 0.029 & $\mathrm{n} / \mathrm{a}$ & 7 & $\mathrm{n} / \mathrm{a}$ & 0.116 & $\mathrm{n} / \mathrm{a}$ \\
\hline & & 2015 & 1.19 & 0.015 & 19 & 6 & 0.018 & 0.012 & 5 & 23 & 0.115 & 0.127 \\
\hline \multirow{2}{*}{\multicolumn{2}{|c|}{ Feature $\mathrm{B}$}} & 2014 & 4.15 & $\mathrm{n} / \mathrm{a}$ & 16 & $\mathrm{n} / \mathrm{a}$ & 0.018 & $\mathrm{n} / \mathrm{a}$ & 4 & $\mathrm{n} / \mathrm{a}$ & 0.105 & $\mathrm{n} / \mathrm{a}$ \\
\hline & & 2015 & 2.95 & $\mathrm{n} / \mathrm{a}$ & 21 & $\mathrm{n} / \mathrm{a}$ & 0.016 & $n / a$ & 4 & $\mathrm{n} / \mathrm{a}$ & 0.270 & $\mathrm{n} / \mathrm{a}$ \\
\hline \multirow{2}{*}{\multicolumn{2}{|c|}{ Feature $\mathrm{C}$}} & 2014 & 1.39 & $\mathrm{n} / \mathrm{a}$ & 18 & $\mathrm{n} / \mathrm{a}$ & 0.014 & $\mathrm{n} / \mathrm{a}$ & 5 & $\mathrm{n} / \mathrm{a}$ & 0.107 & $\mathrm{n} / \mathrm{a}$ \\
\hline & & 2015 & 2.66 & 0.016 & 31 & 6 & 0.016 & 0.012 & 4 & 23 & 0.078 & 0.142 \\
\hline \multirow{2}{*}{\multicolumn{2}{|c|}{ Migneint 2 Feature A }} & 2014 & 1.39 & $\mathrm{n} / \mathrm{a}$ & 24 & $\mathrm{n} / \mathrm{a}$ & 0.014 & $\mathrm{n} / \mathrm{a}$ & 11 & $\mathrm{n} / \mathrm{a}$ & 0.085 & $\mathrm{n} / \mathrm{a}$ \\
\hline & & 2015 & 0.38 & 0.016 & 18 & 15 & 0.020 & 0.016 & 5 & 23 & 0.110 & 0.110 \\
\hline \multirow{2}{*}{\multicolumn{2}{|c|}{ Feature $\mathrm{B}$}} & 2014 & 0.69 & $\mathrm{n} / \mathrm{a}$ & 11 & $\mathrm{n} / \mathrm{a}$ & 0.024 & $\mathrm{n} / \mathrm{a}$ & 5 & $\mathrm{n} / \mathrm{a}$ & 0.127 & $\mathrm{n} / \mathrm{a}$ \\
\hline & & 2015 & 0.35 & 0.016 & 21 & 15 & 0.018 & 0.016 & 6 & 23 & 0.232 & 0.231 \\
\hline \multirow{2}{*}{\multicolumn{2}{|c|}{ Feature $\mathrm{C}$}} & 2014 & 1.83 & $\mathrm{n} / \mathrm{a}$ & 18 & $\mathrm{n} / \mathrm{a}$ & 0.024 & $n / a$ & 4 & $\mathrm{n} / \mathrm{a}$ & 0.079 & $\mathrm{n} / \mathrm{a}$ \\
\hline & & 2015 & 0.85 & 0.016 & 27 & 15 & 0.021 & 0.016 & 6 & 23 & 0.107 & 0.157 \\
\hline \multicolumn{2}{|c|}{ Howgill Fell } & & & & & & & & & & & \\
\hline & Feature A & 2015 & 0.87 & 0.013 & 12 & 28 & 0.016 & 0.034 & 7 & 44 & 0.268 & 0.319 \\
\hline 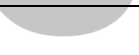 & Feature $B$ & 2015 & 0.93 & 0.013 & 13 & 28 & 0.055 & 0.034 & 7 & 44 & 0.114 & 0.083 \\
\hline \multicolumn{2}{|c|}{ Nateby Moor } & 2015 & 0.82 & 0.019 & 19 & 16 & 0.011 & 0.025 & 5 & 24 & 0.063 & 0.071 \\
\hline & Feature B & 2015 & 0.93 & 0.019 & 16 & 16 & 0.018 & 0.025 & 6 & 24 & 0.059 & 0.087 \\
\hline
\end{tabular}

This article is protected by copyright. All rights reserved. 
Table 4 Gully floor volume estimates and erosion rate estimates for each site.

\begin{tabular}{|c|c|c|c|c|c|}
\hline & \multicolumn{2}{|c|}{$\begin{array}{l}\text { Gully Floor SFM } \\
\text { Volume } \\
\left(\mathrm{m}^{3}\right)\end{array}$} & $\begin{array}{l}\text { Area } \\
\left(\mathrm{m}^{2}\right)\end{array}$ & $\begin{array}{c}\text { Volumetric } \\
\text { change } \\
\left(\mathrm{m}^{3}\right)\end{array}$ & $\begin{array}{l}\text { Mean vertical } \\
\text { erosion } \\
\text { (m) }\end{array}$ \\
\hline Site name & $\begin{array}{l}\text { GP2014 } \\
\text { +/- error }\end{array}$ & $\begin{array}{c}\text { GP } \\
2015 \\
+/- \text { error }\end{array}$ & & & \\
\hline Forest of Bowland & $\begin{array}{c}67.03 \\
+/-3.18\end{array}$ & $\begin{array}{c}76.64 \\
+/-3.18\end{array}$ & 106 & 9.61 & 0.091 \\
\hline Waun Fach B & $\begin{array}{c}60.01 \\
+/-8.13\end{array}$ & $\begin{array}{c}76.02 \\
+/-8.13\end{array}$ & 271 & 16.01 & 0.059 \\
\hline Southern Scar E & $\begin{array}{c}54.08 \\
+/-7.14\end{array}$ & $\begin{array}{c}46.6 \\
+/-7.14\end{array}$ & 238 & -7.48 & -0.031 \\
\hline Southern Scar F & $\begin{array}{c}94.2 \\
+/-6.09\end{array}$ & $\begin{array}{r}93.75 \\
+/-6.09\end{array}$ & 203 & -0.45 & -0.002 \\
\hline Southern Scar G & $\begin{array}{c}98.72 \\
+/-22.29\end{array}$ & $\begin{array}{c}98.25 \\
+/- \\
22.29\end{array}$ & 743 & -0.47 & 0.000 \\
\hline Migneint $1 / \mathrm{A}$ & $\begin{array}{c}31.24 \\
+/-2.73\end{array}$ & $\begin{array}{c}33.54 \\
+/-2.73\end{array}$ & 91 & 2.30 & 0.025 \\
\hline Migneint $1 \mathrm{~B}$ & $\begin{array}{r}14.05 \\
+/-0.9\end{array}$ & $\begin{array}{r}17.28 \\
+/-0.9\end{array}$ & 30 & 3.23 & 0.108 \\
\hline Migneint $1 \mathrm{C}$ & $\begin{array}{c}15.16 \\
+/-0.93\end{array}$ & $\begin{array}{c}15.79 \\
+/-0.93\end{array}$ & 31 & 0.63 & 0.020 \\
\hline Migneint $2 \mathrm{~A}$ & $\begin{array}{l}178.66 \\
+/-7.74\end{array}$ & $\begin{array}{c}186.03 \\
+/-7.74\end{array}$ & 258 & 7.37 & 0.286 \\
\hline Migneint $2 \mathrm{~B}$ & $\begin{array}{c}40.25 \\
+/-3.96 \\
\end{array}$ & $\begin{array}{c}48.02 \\
+/-3.96 \\
\end{array}$ & 132 & 7.77 & 0.059 \\
\hline Migneint $2 \mathrm{C}$ & $\begin{array}{c}58.14 \\
+/-3.12\end{array}$ & $\begin{array}{c}59.23 \\
+/-3.12\end{array}$ & 104 & 1.09 & 0.010 \\
\hline Mean & & & & 3.60 & 0.033 \\
\hline
\end{tabular}


Table 5 Comparison of the cost-effectiveness of the three deployed techniques per site and per hectare area surveyed. The mean time estimates for the 10 sites include two operators for each technique to allow for fieldwork safety considerations.

\begin{tabular}{|c|c|c|c|c|c|c|}
\hline & \multicolumn{2}{|c|}{$\begin{array}{l}\text { UAV } \\
\text { (hours) }\end{array}$} & \multicolumn{2}{|c|}{$\begin{array}{c}\text { TLS } \\
\text { (hours) }\end{array}$} & \multicolumn{2}{|c|}{$\begin{array}{c}\text { GP } \\
\text { (hours) }\end{array}$} \\
\hline & per site & $\begin{array}{c}\text { per ha } \\
\text { surveyed }\end{array}$ & per site & $\begin{array}{c}\text { per ha } \\
\text { surveyed }\end{array}$ & per site & $\begin{array}{l}\text { per ha } \\
\text { surveyed }\end{array}$ \\
\hline $\begin{array}{l}\text { Field data capture (initial } \\
\text { walk over survey, site } \\
\text { marking, field surveying) }\end{array}$ & 10.4 & 3.5 & 6.5 & 1.9 & 5.0 & 77.4 \\
\hline $\begin{array}{l}\text { Post-processing CPU } \\
\text { time }\end{array}$ & 2.6 & 0.9 & 13.3 & 3.9 & 39.4 & 606.0 \\
\hline $\begin{array}{l}\text { Post-processing person } \\
\text { time (data cleaning, point } \\
\text { cloud registration, DEM } \\
\text { elaboration) }\end{array}$ & 3.0 & 1.0 & 6.9 & 2.0 & 3.2 & 49.6 \\
\hline $\begin{array}{l}\text { Mean person time per } \\
\text { technique }\end{array}$ & 13.4 & 4.5 & 13.4 & 3.9 & 8.2 & 127.0 \\
\hline $\begin{array}{l}\text { Approx. cost of equipment } \\
\text { (incl. hardware and } \\
\text { software) }\end{array}$ & \multicolumn{2}{|c|}{$£ 1,500$} & \multicolumn{2}{|c|}{$£ 100,000$} & \multicolumn{2}{|c|}{$£ 750$} \\
\hline
\end{tabular}




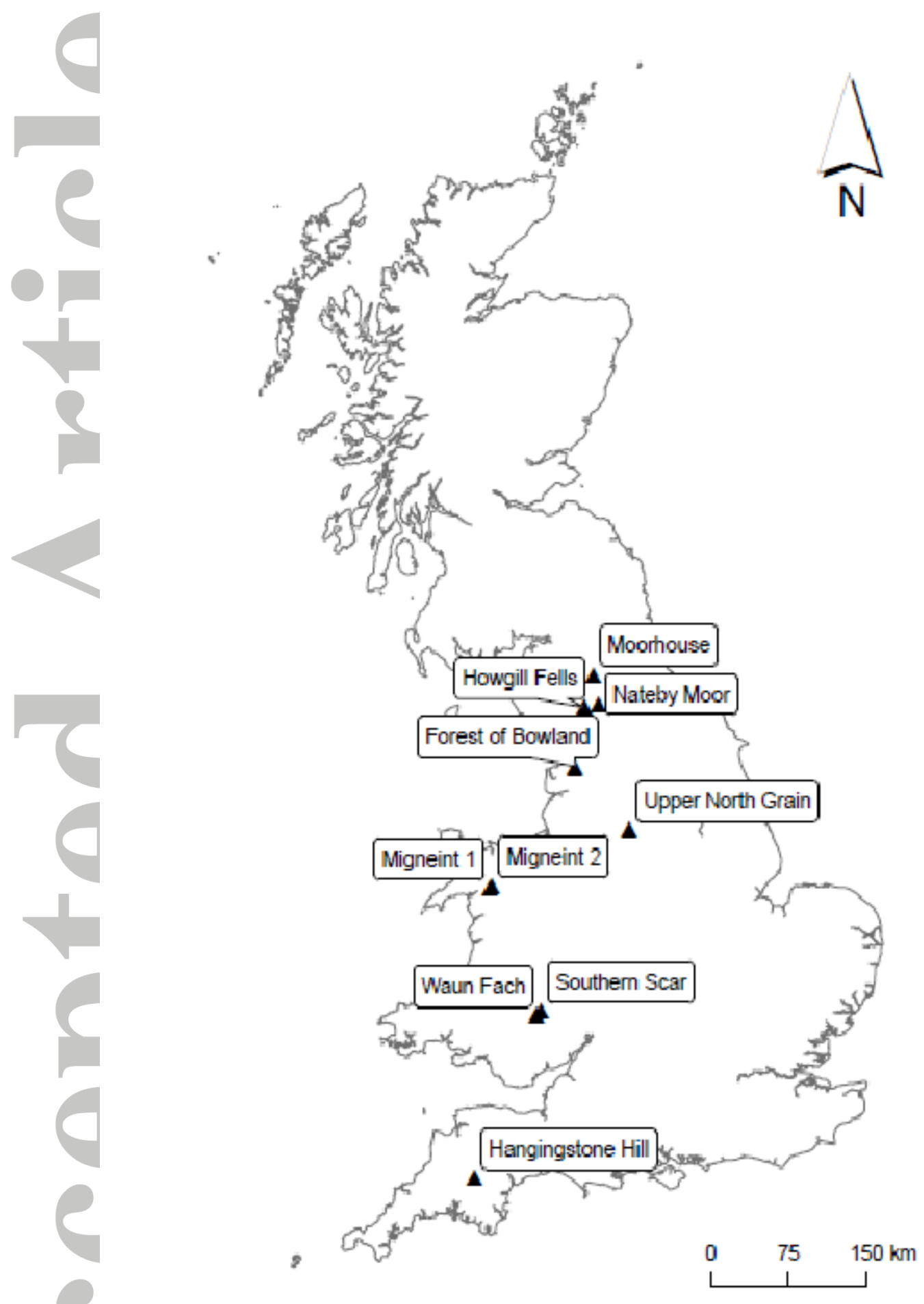

Fig. 1 Location of the 10 upland study sites in England and Wales. 

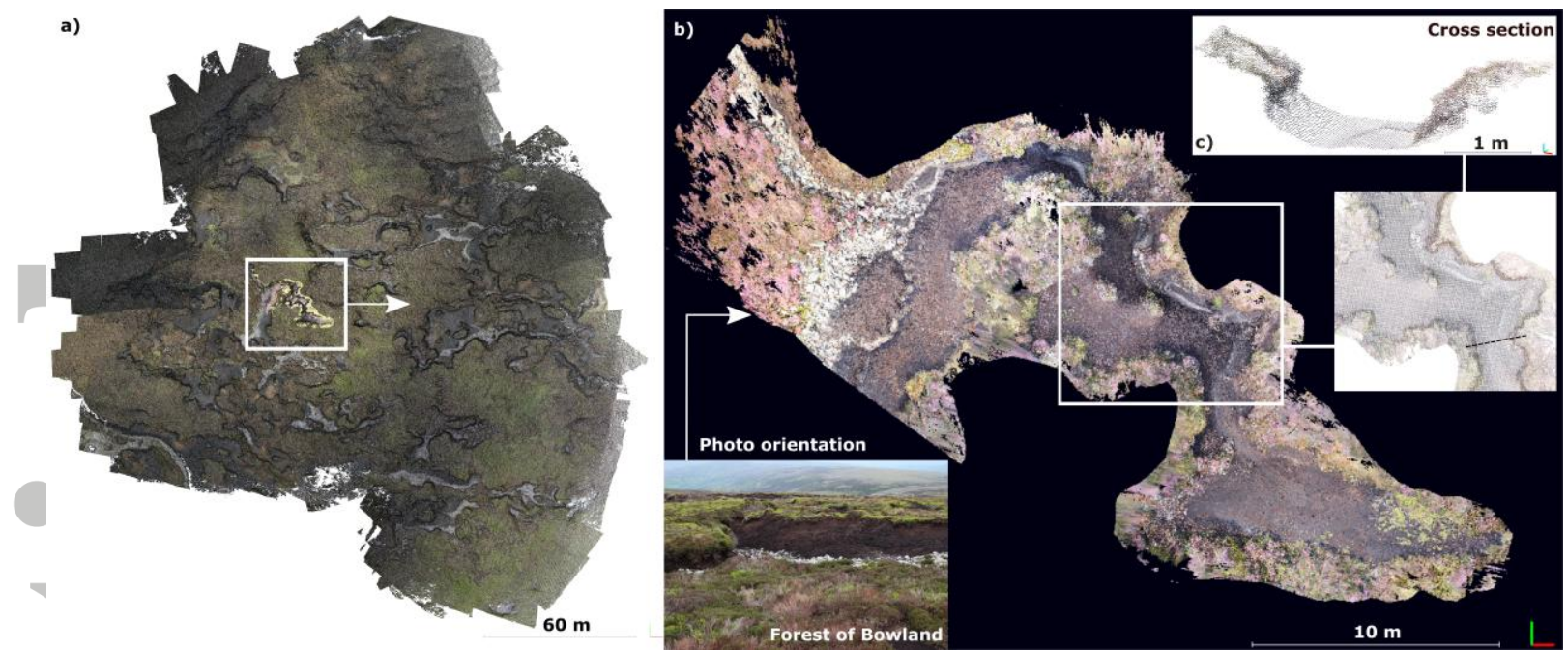

Fig. 2 Schematic showing a) a point cloud derived from a UAV SfM survey at Forest of Bowland, with a GP SfM gully model superimposed b) The GP SfM point cloud model in detail with c) an example cross-section.

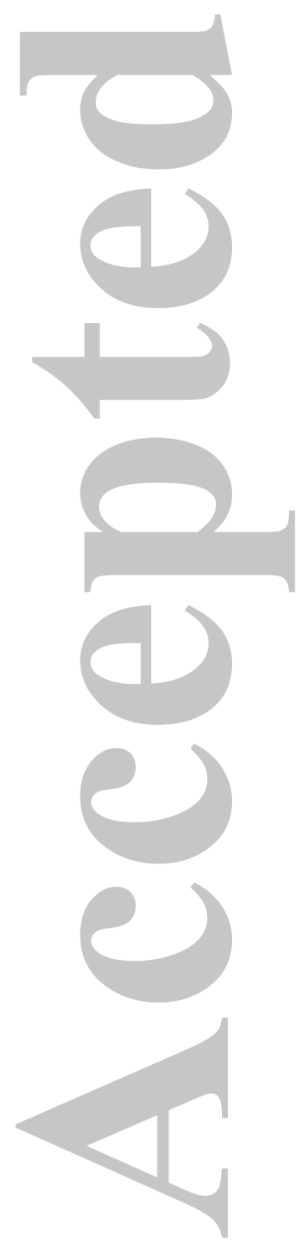



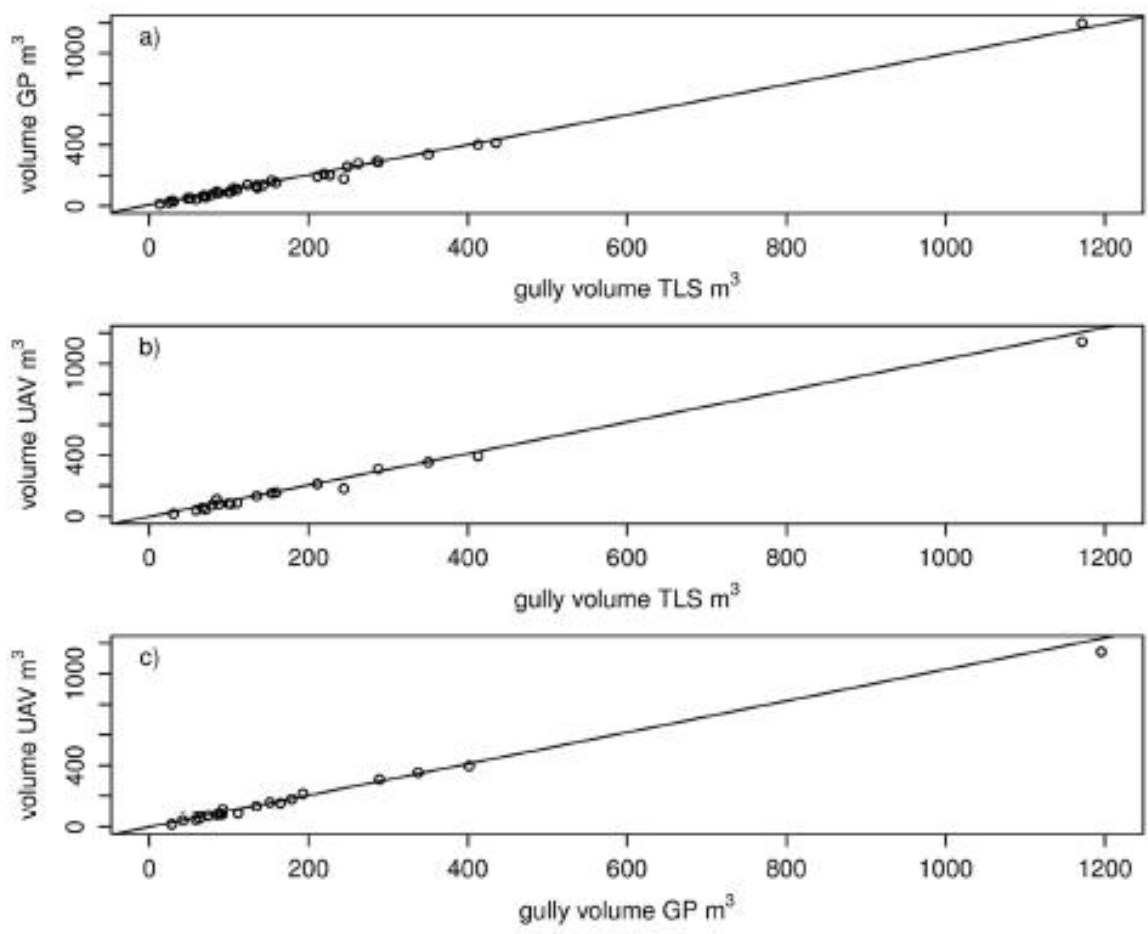

Fig. 3 Relationships between gully volume estimates made by a) GP and TLS b) UAV and TLS c) GP and UAV. Lines represent the line of best fit using linear regression. 

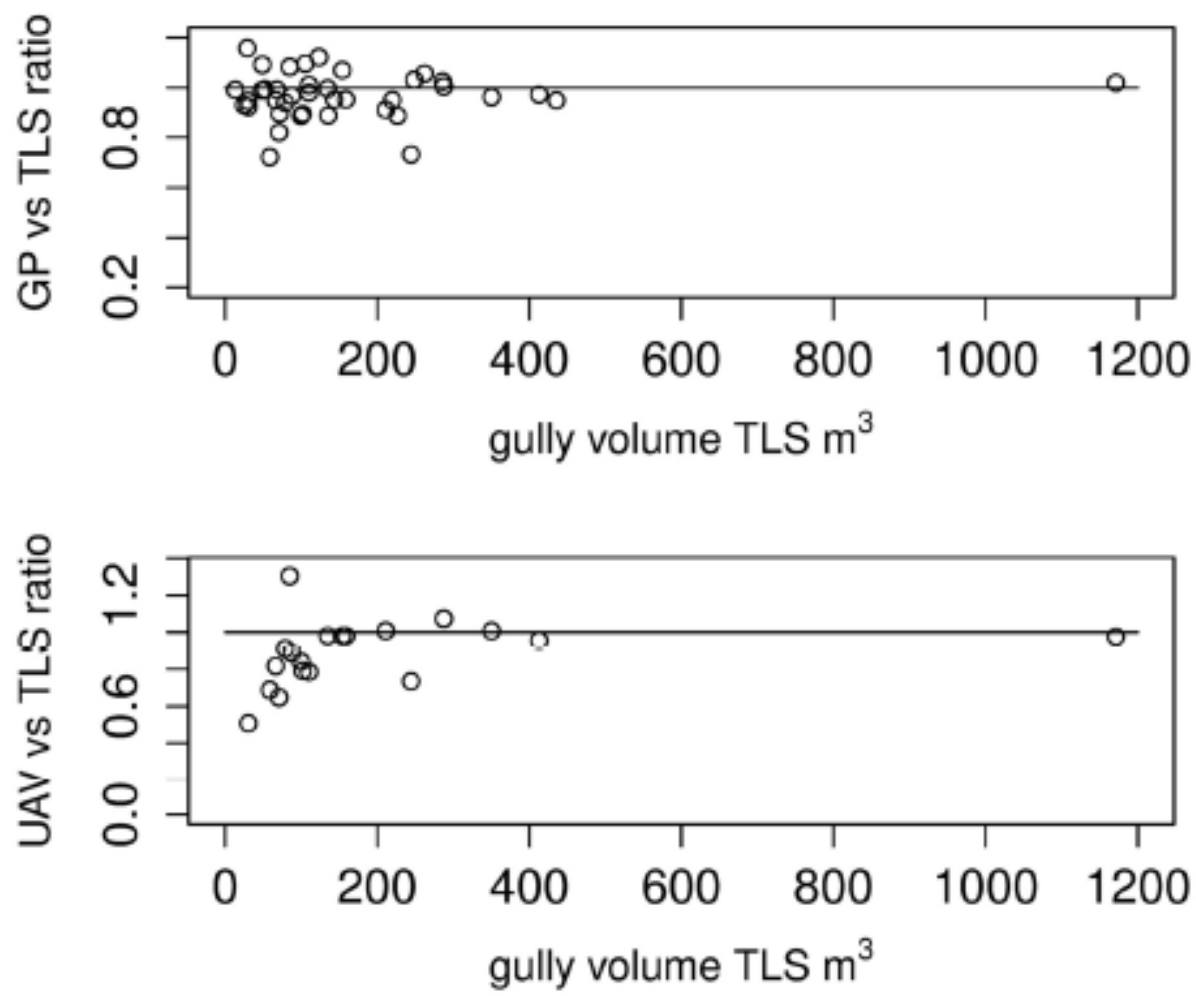

Fig. 4 Ratio between gully volume estimates derived from a) GP and TLS and b)

UAV and TLS techniques. The lines represent perfect fit with a ratio $=1$ 


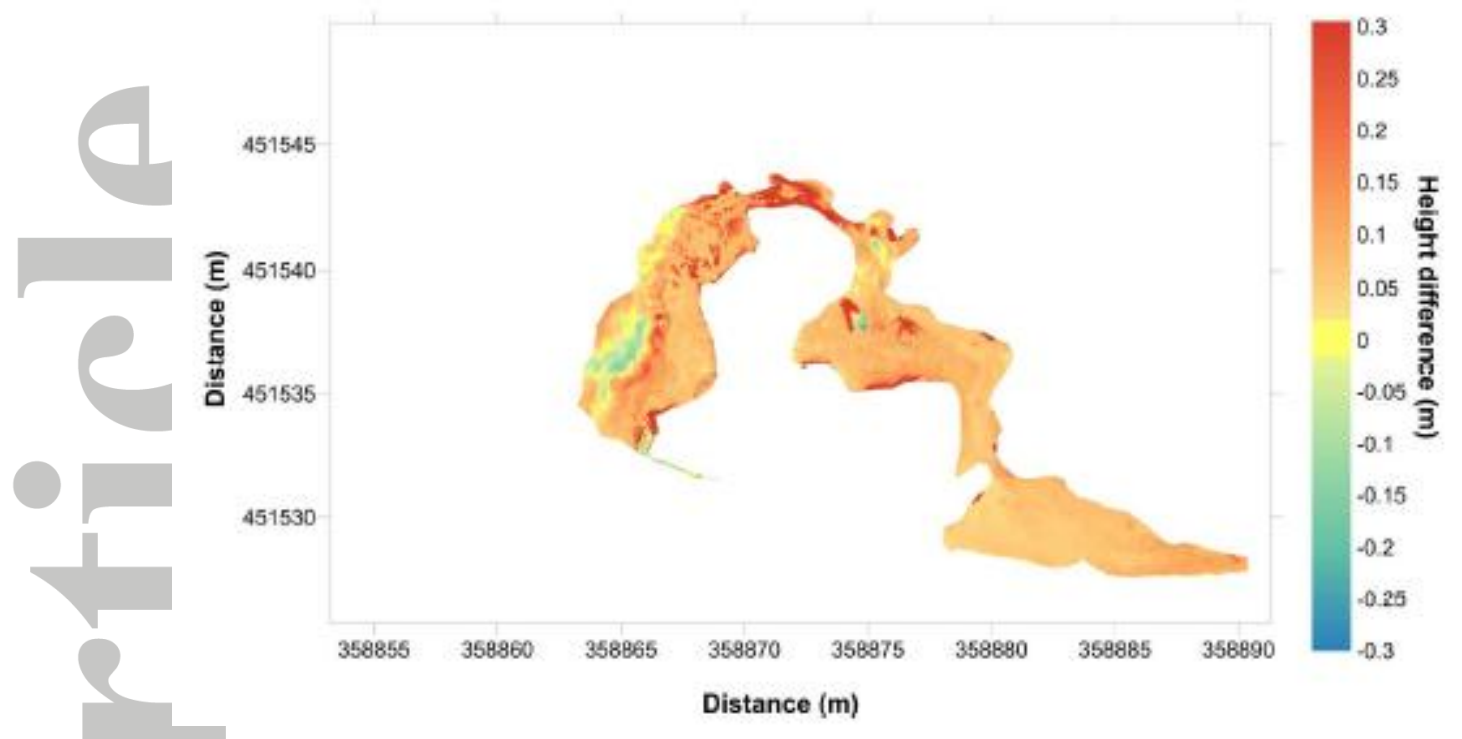

Fig. 5 DEM of difference 2015-2014 cropped to include only bare ground within eroding gullies, for gully floor at Forest of Bowland shown in Fig 2. Positive values represent erosion. It is apparent that significant erosion is recorded at this site (mean vertical erosion $0.091 \mathrm{~m} \mathrm{a}^{-1}$ ). 


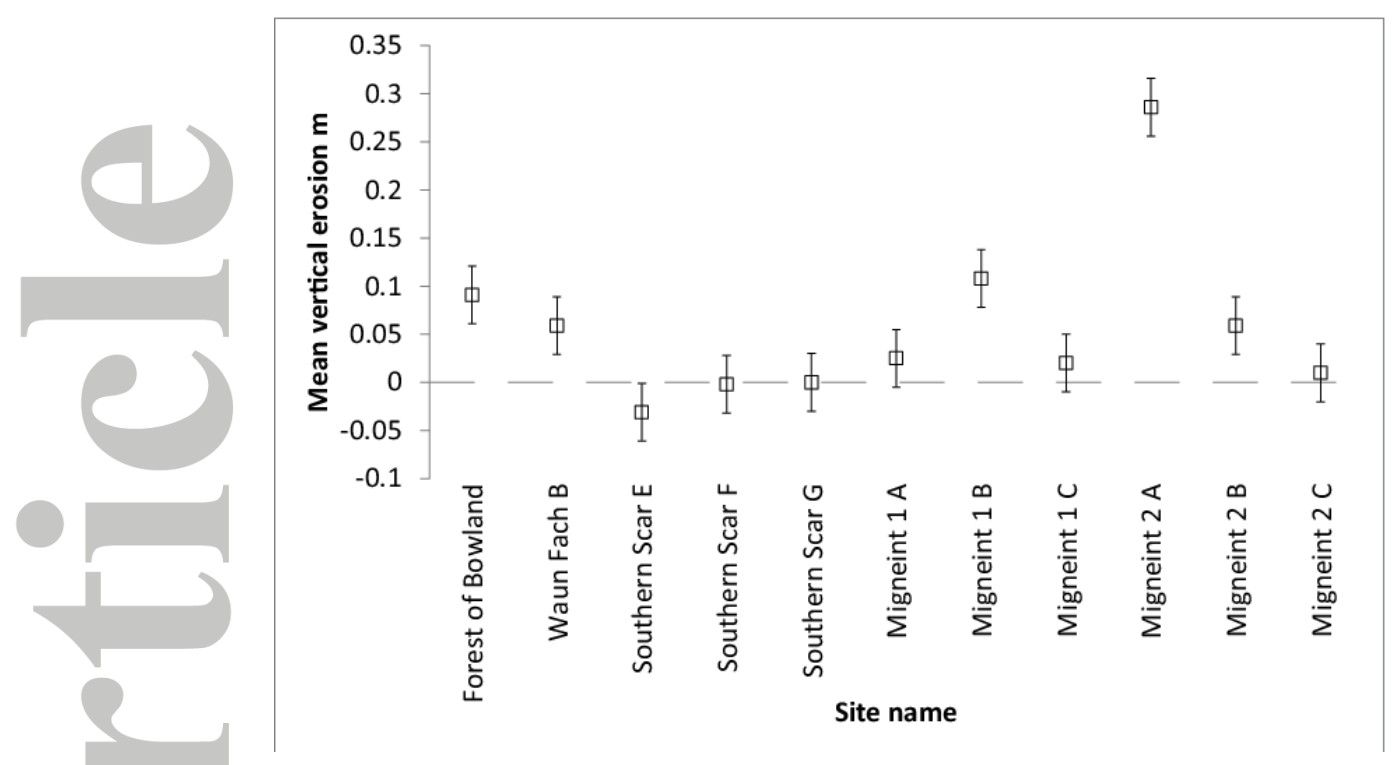

Fig. 6 Mean vertical change in gully floor erosion at four survey sites. Error bars show the $3 \mathrm{~cm}$ accuracy of the DGPS device.

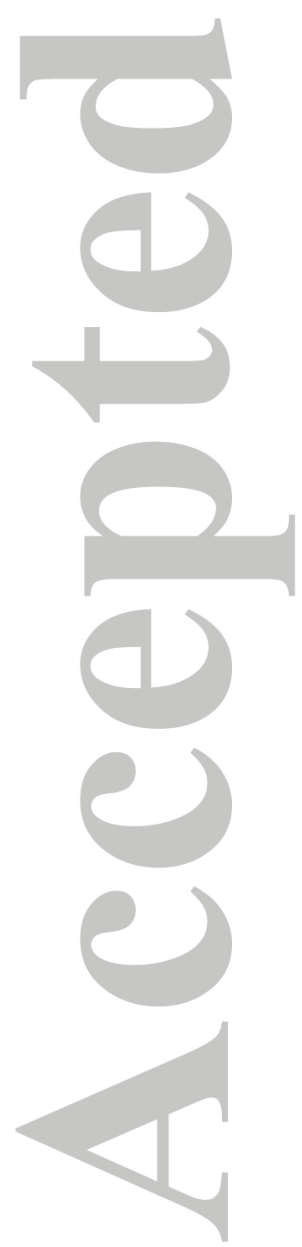


Appendix 1 Derived erosion estimates for all features surveyed at the 10 study sites.

\begin{tabular}{|c|c|c|c|c|c|c|c|c|c|c|}
\hline \multirow[t]{2}{*}{ Site and feature } & \multirow[t]{2}{*}{ Description } & \multirow[t]{2}{*}{$\begin{array}{c}\text { Survey } \\
\text { year }\end{array}$} & \multicolumn{3}{|c|}{$\begin{array}{l}\text { Estimated volume } \\
\qquad\left(\mathrm{m}^{3}\right)\end{array}$} & \multicolumn{2}{|c|}{$\begin{array}{l}\text { Relative error in } \\
\text { volume estimation } \\
\text { (\%) }\end{array}$} & \multicolumn{2}{|c|}{$\begin{array}{c}\text { Volume difference } \\
\text { ratio }\end{array}$} & \multirow[t]{2}{*}{$\begin{array}{l}\text { Gully } \\
\text { area } \\
\left(\mathrm{m}^{2}\right)\end{array}$} \\
\hline & & & GP & TLS & UAV & GP & UAV & GP/TLS & UAV/TLS & \\
\hline Forest of & Narrow peat & 2014 & 138.4 & 123.3 & $n / a$ & 12.25 & $\mathrm{n} / \mathrm{a}$ & 1.12 & $\mathrm{n} / \mathrm{a}$ & 360 \\
\hline Bowland & gully & 2015 & 151.6 & 158.9 & 155.8 & -4.59 & -1.95 & 0.95 & 0.98 & \\
\hline Howgill Fells & $\begin{array}{l}\text { Shallow sheep } \\
\text { scar, upland } \\
\text { grassland }\end{array}$ & 2014 & 256.7 & 248.6 & $\mathrm{n} / \mathrm{a}$ & 3.26 & $\mathrm{n} / \mathrm{a}$ & 1.03 & $\mathrm{n} / \mathrm{a}$ & 247 \\
\hline Waun Fach B & $\begin{array}{l}\text { Shallow gully, } \\
\text { upland } \\
\text { grassland }\end{array}$ & 2014 & 136.7 & 143.3 & $\mathrm{n} / \mathrm{a}$ & -4.61 & $n / a$ & 0.95 & $\mathrm{n} / \mathrm{a}$ & 535 \\
\hline & Shallow broken & 2014 & 277.1 & 262.2 & $n / a$ & 5.68 & $n / a$ & 1.06 & $n / a$ & 1073 \\
\hline Waun Fach C & $\begin{array}{l}\text { ground/footpath, } \\
\text { UG }\end{array}$ & 2015 & 92 & 84.9 & 110.7 & 8.36 & 30.39 & 1.08 & 1.30 & \\
\hline Waun Fach D & $\begin{array}{l}\text { Shallow broken } \\
\text { ground, UG }\end{array}$ & 2014 & 13.1 & 13.2 & $\mathrm{n} / \mathrm{a}$ & -0.76 & $\mathrm{n} / \mathrm{a}$ & 0.99 & $\mathrm{n} / \mathrm{a}$ & 219 \\
\hline Southern Scar E & Shallow, fire & 2014 & 67.7 & 68.2 & $\mathrm{n} / \mathrm{a}$ & -0.73 & $\mathrm{n} / \mathrm{a}$ & 0.99 & $\mathrm{n} / \mathrm{a}$ & 442 \\
\hline
\end{tabular}

This article is protected by copyright. All rights reserved. 


\begin{tabular}{|c|c|c|c|c|c|c|c|c|c|c|}
\hline \multirow[t]{3}{*}{ Site and feature } & \multirow[t]{2}{*}{ Description } & \multirow[t]{2}{*}{$\begin{array}{c}\text { Survey } \\
\text { year }\end{array}$} & \multicolumn{3}{|c|}{$\begin{array}{l}\text { Estimated volume } \\
\qquad\left(\mathrm{m}^{3}\right)\end{array}$} & \multicolumn{2}{|c|}{$\begin{array}{l}\text { Relative error in } \\
\text { volume estimation } \\
\text { (\%) }\end{array}$} & \multicolumn{2}{|c|}{$\begin{array}{c}\text { Volume difference } \\
\text { ratio }\end{array}$} & \multirow[t]{2}{*}{$\begin{array}{l}\text { Gully } \\
\text { area } \\
\left(\mathrm{m}^{2}\right)\end{array}$} \\
\hline & & & GP & TLS & UAV & GP & UAV & GP/TLS & UAV/TLS & \\
\hline & $\begin{array}{l}\text { damaged peat } \\
\text { gully }\end{array}$ & 2015 & 58.2 & 71 & 45.9 & -18.03 & -35.35 & 0.82 & 0.65 & \\
\hline & & 2014 & 51.8 & 52.1 & $\mathrm{n} / \mathrm{a}$ & -0.58 & $\mathrm{n} / \mathrm{a}$ & 0.99 & $\mathrm{n} / \mathrm{a}$ & 303 \\
\hline Southern Scar F & $\begin{array}{l}\text { damaged peat } \\
\text { gully }\end{array}$ & 2015 & 53.3 & 48.8 & $\mathrm{n} / \mathrm{a}$ & 9.22 & $\mathrm{n} / \mathrm{a}$ & 1.09 & $n / a$ & \\
\hline \multirow{2}{*}{$\begin{array}{l}\text { Southern Scar } \\
\text { G }\end{array}$} & Wide, fire & 2014 & 209 & 219.6 & $\mathrm{n} / \mathrm{a}$ & -4.83 & $\mathrm{n} / \mathrm{a}$ & 0.95 & $\mathrm{n} / \mathrm{a}$ & \multirow[t]{2}{*}{1238} \\
\hline & $\begin{array}{l}\text { damaged peat } \\
\text { gully }\end{array}$ & 2015 & 192.8 & 211.2 & 213 & -8.71 & 0.85 & 0.91 & 1.01 & \\
\hline $\begin{array}{l}\text { Upper North } \\
\text { Grain A }\end{array}$ & $\begin{array}{l}\text { Narrow, deep } \\
\text { steep-sided peat } \\
\text { gully }\end{array}$ & 2014 & 289.3 & 287.6 & 308.9 & 0.59 & 7.41 & 1.01 & 1.07 & 435 \\
\hline $\begin{array}{l}\text { Upper North } \\
\text { Grain B }\end{array}$ & $\begin{array}{l}\text { Narrow, deep } \\
\text { steep-sided peat } \\
\text { gully }\end{array}$ & 2014 & 293.4 & 286 & $\mathrm{n} / \mathrm{a}$ & 2.59 & $\mathrm{n} / \mathrm{a}$ & 1.03 & $\mathrm{n} / \mathrm{a}$ & 461 \\
\hline Upper North & Narrow, deep & 2014 & 64.2 & 71.7 & $\mathrm{n} / \mathrm{a}$ & -10.46 & $\mathrm{n} / \mathrm{a}$ & 0.90 & $\mathrm{n} / \mathrm{a}$ & 178 \\
\hline
\end{tabular}

This article is protected by copyright. All rights reserved. 


\begin{tabular}{|c|c|c|c|c|c|c|c|c|c|c|}
\hline \multirow[t]{2}{*}{ Site and feature } & \multirow[t]{2}{*}{ Description } & \multirow[t]{2}{*}{$\begin{array}{l}\text { Survey } \\
\text { year }\end{array}$} & \multicolumn{3}{|c|}{$\begin{array}{l}\text { Estimated volume } \\
\qquad\left(\mathrm{m}^{3}\right)\end{array}$} & \multicolumn{2}{|c|}{$\begin{array}{c}\text { Relative error in } \\
\text { volume estimation } \\
\text { (\%) }\end{array}$} & \multicolumn{2}{|c|}{$\begin{array}{l}\text { Volume difference } \\
\text { ratio }\end{array}$} & \multirow[t]{2}{*}{$\begin{array}{l}\text { Gully } \\
\text { area } \\
\left(\mathrm{m}^{2}\right)\end{array}$} \\
\hline & & & GP & TLS & UAV & GP & UAV & GP/TLS & UAV/TLS & \\
\hline Grain C & $\begin{array}{l}\text { steep-sided peat } \\
\text { gully }\end{array}$ & & & & & & & & & \\
\hline $\begin{array}{l}\text { Upper North } \\
\text { Grain D }\end{array}$ & $\begin{array}{l}\text { Shallow broken- } \\
\text { ground, peat }\end{array}$ & 2014 & 108.1 & 110.2 & $\mathrm{n} / \mathrm{a}$ & -1.91 & $\mathrm{n} / \mathrm{a}$ & 0.98 & $\mathrm{n} / \mathrm{a}$ & 666 \\
\hline $\begin{array}{l}\text { Hangingstone } \\
\text { Hill A }\end{array}$ & $\begin{array}{l}\text { Wide, peat-hag } \\
\text { bog }\end{array}$ & 2014 & 63.2 & 66.5 & 54.3 & -4.96 & -18.35 & 0.95 & 0.82 & 214 \\
\hline $\begin{array}{l}\text { Hangingstone } \\
\text { Hill B }\end{array}$ & $\begin{array}{l}\text { Wide vegetated } \\
\text { gully channel }\end{array}$ & 2014 & 91.3 & 102 & 80.7 & -10.49 & -20.88 & 0.90 & 0.79 & 336 \\
\hline $\begin{array}{l}\text { Hangingstone } \\
\text { Hill C }\end{array}$ & $\begin{array}{l}\text { Wide vegetated } \\
\text { gully channel }\end{array}$ & 2014 & 88.4 & 99.7 & 83.8 & -11.33 & -15.95 & 0.89 & 0.84 & 283 \\
\hline Moorhouse A & $\begin{array}{l}\text { Wide vegetated } \\
\text { gully channel }\end{array}$ & 2014 & 134.4 & 134.8 & 132.2 & -0.30 & -1.93 & 1.00 & 0.98 & 195 \\
\hline Moorhouse B & $\begin{array}{l}\text { Wide vegetated } \\
\text { gully channel }\end{array}$ & 2014 & 120.3 & 135.4 & $\mathrm{n} / \mathrm{a}$ & -11.15 & $\mathrm{n} / \mathrm{a}$ & 0.89 & $\mathrm{n} / \mathrm{a}$ & 486 \\
\hline Moorhouse C & Wide, deep & 2014 & 164.9 & 154.0 & 151.0 & 7.08 & -1.95 & 1.07 & 0.98 & 362 \\
\hline
\end{tabular}

This article is protected by copyright. All rights reserved. 


\begin{tabular}{|c|c|c|c|c|c|c|c|c|c|c|}
\hline \multirow[t]{2}{*}{ Site and feature } & \multirow[t]{2}{*}{ Description } & \multirow[t]{2}{*}{$\begin{array}{c}\text { Survey } \\
\text { year }\end{array}$} & \multicolumn{3}{|c|}{$\begin{array}{l}\text { Estimated volume } \\
\qquad\left(\mathrm{m}^{3}\right)\end{array}$} & \multicolumn{2}{|c|}{$\begin{array}{l}\text { Relative error in } \\
\text { volume estimation } \\
\text { (\%) }\end{array}$} & \multicolumn{2}{|c|}{$\begin{array}{c}\text { Volume difference } \\
\text { ratio }\end{array}$} & \multirow[t]{2}{*}{$\begin{array}{l}\text { Gully } \\
\text { area } \\
\left(\mathrm{m}^{2}\right)\end{array}$} \\
\hline & & & GP & TLS & UAV & GP & UAV & GP/TLS & UAV/TLS & \\
\hline & $\begin{array}{l}\text { vegetated gully } \\
\text { channel }\end{array}$ & & & & & & & & & \\
\hline \multirow{2}{*}{ Migneint $1 \mathrm{~A}$} & Narrow, peat- & 2014 & 47.9 & 48.4 & $\mathrm{n} / \mathrm{a}$ & -1.03 & $\mathrm{n} / \mathrm{a}$ & 0.99 & $\mathrm{n} / \mathrm{a}$ & \multirow[t]{2}{*}{205} \\
\hline & hag bog & 2015 & 42.3 & 58.6 & 40.3 & -27.82 & -31.23 & 0.72 & 0.69 & \\
\hline \multirow{2}{*}{ Migneint $1 \mathrm{~B}$} & Narrow peat & 2014 & 23 & 24.7 & $\mathrm{n} / \mathrm{a}$ & -6.88 & $\mathrm{n} / \mathrm{a}$ & 0.93 & $\mathrm{n} / \mathrm{a}$ & \multirow[t]{2}{*}{104} \\
\hline & gully & 2015 & 33.6 & 29.0 & $\mathrm{n} / \mathrm{a}$ & 15.86 & $\mathrm{n} / \mathrm{a}$ & 1.16 & $\mathrm{n} / \mathrm{a}$ & \\
\hline \multirow{2}{*}{ Migneint $1 \mathrm{C}$} & Narrow peat & 2014 & 28.6 & 30.2 & $\mathrm{n} / \mathrm{a}$ & -5.30 & $\mathrm{n} / \mathrm{a}$ & 0.95 & $\mathrm{n} / \mathrm{a}$ & \multirow[t]{2}{*}{137} \\
\hline & gully & 2015 & 28.2 & 30.5 & 15.5 & -7.54 & -49.18 & 0.92 & 0.51 & \\
\hline \multirow[b]{2}{*}{ Migneint $2 \mathrm{~A}$} & Wide, deep & 2014 & 414 & 435.6 & $\mathrm{n} / \mathrm{a}$ & -4.96 & $n / a$ & 0.95 & $n / a$ & \multirow[t]{2}{*}{619} \\
\hline & $\begin{array}{l}\text { vegetated gully } \\
\text { channel }\end{array}$ & 2015 & 401.9 & 412.9 & 394.8 & -2.66 & -4.38 & 0.97 & 0.96 & \\
\hline \multirow[b]{2}{*}{ Migneint 2 B } & \multirow{2}{*}{$\begin{array}{l}\text { Wide, deep } \\
\text { vegetated gully } \\
\text { channel }\end{array}$} & 2014 & 201 & 226.5 & $\mathrm{n} / \mathrm{a}$ & -11.26 & $\mathrm{n} / \mathrm{a}$ & 0.89 & $\mathrm{n} / \mathrm{a}$ & 714 \\
\hline & & 2015 & 178.9 & 244.4 & 179.5 & -26.80 & -26.55 & 0.73 & 0.73 & \\
\hline Migneint $2 \mathrm{C}$ & Wide, deep & 2014 & 115.7 & 105.5 & $\mathrm{n} / \mathrm{a}$ & 9.67 & $\mathrm{n} / \mathrm{a}$ & 1.10 & $\mathrm{n} / \mathrm{a}$ & 308 \\
\hline
\end{tabular}

This article is protected by copyright. All rights reserved. 


\begin{tabular}{|c|c|c|c|c|c|c|c|c|c|c|}
\hline \multirow[t]{3}{*}{ Site and feature } & \multirow{3}{*}{$\begin{array}{l}\text { Description } \\
\text { vegetated gully } \\
\text { channel }\end{array}$} & \multirow[t]{2}{*}{$\begin{array}{c}\text { Survey } \\
\text { year }\end{array}$} & \multicolumn{3}{|c|}{$\begin{array}{l}\text { Estimated volume } \\
\qquad\left(\mathrm{m}^{3}\right)\end{array}$} & \multicolumn{2}{|c|}{$\begin{array}{c}\text { Relative error in } \\
\text { volume estimation } \\
\text { (\%) }\end{array}$} & \multicolumn{2}{|c|}{$\begin{array}{c}\text { Volume difference } \\
\text { ratio }\end{array}$} & \multirow[t]{2}{*}{$\begin{array}{l}\text { Gully } \\
\text { area } \\
\left(\mathrm{m}^{2}\right)\end{array}$} \\
\hline & & & GP & TLS & UAV & GP & UAV & GP/TLS & UAV/TLS & \\
\hline & & 2015 & 111.4 & 110.2 & 86.5 & 1.09 & -21.51 & 1.01 & 0.78 & \\
\hline Howgill A & $\begin{array}{l}\text { Deep scar, } \\
\text { upland } \\
\text { grassland }\end{array}$ & 2015 & 1195.4 & 1171.4 & 1143.5 & 2.05 & -2.38 & 1.02 & 0.98 & 525 \\
\hline Howgill B & $\begin{array}{l}\text { Deep scar, } \\
\text { upland } \\
\text { grassland }\end{array}$ & 2015 & 337.6 & 350.3 & 353.0 & -3.63 & 0.77 & 0.06 & 1.01 & 313 \\
\hline Nateby Moor A & $\begin{array}{l}\text { Narrow peat } \\
\text { gully }\end{array}$ & 2015 & 74.2 & 78.9 & 71.9 & -5.96 & -8.87 & 0.94 & 0.91 & 232 \\
\hline Nateby Moor B & $\begin{array}{l}\text { Narrow peat } \\
\text { gully }\end{array}$ & 2015 & 84.8 & 87.6 & 77.6 & -3.20 & -11.42 & 0.97 & 0.89 & 165 \\
\hline
\end{tabular}

This article is protected by copyright. All rights reserved. 